\title{
Ireland: The Constitution of Ireland and EU Law: The Complex Constitutional Debates of a Small Country
}

\author{
Gerard Hogan
}

\begin{abstract}
The 1937 Constitution of Ireland draws on the following three main influences: (1) the US Constitution as regards judicial review of legislation; (2) UK common law heritage regarding the fused Westminster style legislative/executive model; and (3) a variety of continental constitutions regarding some fundamental rights. The report observes that apart from constitutional guarantees on fair trial and habeas corpus, most fundamental rights provisions are expressed at a high level of generality. A distinctive feature is that the Constitution can only be amended by a referendum, and this is indeed frequently done, including with regard to EU law. The central EU amendment is the so-called 'necessitated obligations' clause (Art. 29.4.(6)), which has the effect of overriding all other constitutional provisions. The Constitution is a key part of the political debate, and extensive constitutional issues have also arisen in relation to EU law. Three of the most important data retention cases that have come before the ECJ have all originated from Ireland. Another notable case is Pringle, where an MP raised concerns about the large size of the financial liabilities undertaken by the ESM Treaty. With regard to the European Arrest Warrant, whilst the Irish courts carry out more extensive judicial review, the automaticity involved in mutual recognition has nevertheless been a constant source of concern for judges. The rule of parliamentary reservation of law has led to extensive adjudication, e.g. in relation to the introduction of indictable offences by governmental regulations under EU measures, and in relation to the ratification of an IMF loan agreement and an extradition treaty.
\end{abstract}

Keywords The Constitution of Ireland - The Supreme Court of Ireland Constitutional amendments regarding EU and international co-operation The 'necessitated obligations' clause/Article 29(6) • Fundamental rights

Gerard Hogan is Advocate General at the Court of Justice of the European Union; at the time of writing, Judge at the Court of Appeal of Ireland. e-mail: gerard.hogan@curia.europa.eu.

All websites accessed 16 October 2015. Text submitted 24 July 2015.

G. Hogan $(\bowtie)$

European Court of Justice, Luxembourg, Luxembourg

e-mail: gerard.hogan@curia.europa.eu

(C) The Author(s) 2019

A. Albi and S. Bardutzky (eds.), National Constitutions in European

and Global Governance: Democracy, Rights, the Rule of Law,

https://doi.org/10.1007/978-94-6265-273-6_28 
Digital Rights Ireland and the Data Retention Directive $\cdot$ Schrems European Arrest Warrant, mutual recognition, automaticity of extraditions, defence rights and judicial review - Pringle and the ESM Treaty - Meagher, Maher, indictable offences and parliamentary reservation of law - Property rights Crotty and referendums - Ratification of an IMF loan agreement and an extradition treaty by governmental regulations

\section{Constitutional Amendments Regarding EU Membership}

\subsection{Constitutional Culture}

1.1.1 The Constitution of Ireland entered into force on 29 December 1937 following its approval at a referendum which was held on 1 July $1937 .^{1}$ Since June 1941 the Constitution can only be amended by means of a referendum. It replaced the Constitution of the Irish Free State 1922, although key elements of that Constitution were preserved. That Constitution itself was the product of the Anglo-Irish War of 1919-1921 and the subsequent Treaty of December 1921.

Despite the (relative) frequency with which the Constitution has been amended, its basic structure has remained unchanged. In general, it may be said that the majority of the amendments have been designed either to delete the more nationalistic $^{2}$ or specifically Roman Catholic inspired provisions ${ }^{3}$ or to deal with the various amendments to EU Treaties. Several amendments deal with the vexed question of abortion. Perhaps the single biggest institutional change has been the creation of a new Court of Appeal in October 2014 and the (de facto) re-constitution of the Supreme Court along US lines. ${ }^{4}$

1.1.2 The Constitution mandates a (relatively) strict separation of powers, save that it follows the fused legislative/executive model in the Westminster style. It is also quite prescriptive in terms of matters such as parliamentary privilege, elections,

\footnotetext{
${ }^{1}$ See generally, Hogan 2012.

${ }^{2}$ Thus, for example, the territorial claim to Northern Ireland contained in the original Art. 2 and Art. 3 of the Constitution was deleted by the 19th Amendment of the Constitution Act 1998, which also gives effect to aspects of the Belfast Agreement between the UK and Ireland. See generally Hogan 2000.

${ }^{3}$ Thus, for example, the 5th Amendment of the Constitution Act 1972 deleted the reference to the 'special position' of the Roman Catholic Church 'as guardian of the faith professed by the great majority of the citizens', along with the named recognition of other religious denominations and 'the Jewish Congregations'.

${ }^{4}$ By the 33rd Amendment of the Constitution (Court of Appeal) Act 2013 which came into effect on 28 October 2014. The practical effect of this was that all appeals now go from the High Court to the Court of Appeal. The decision of that Court is final save for those cases where the case either raises a point of law of exceptional importance or the interests of justice so require. There is also provision for 'leapfrog' appeals directly from the High Court to the Supreme Court, also confined to exceptional cases.
} 
legislative procedure, executive powers and the powers of the (largely ceremonial) President. It gives strikingly impressive powers of judicial review of legislation to the High Court, Courts of Appeal and the Supreme Court. The Constitution also contains elaborate protections for a range of civil and political rights, including trial in due course of law, equality before the law, the protection of life, person, good name and property rights, liberty and habeas corpus, the home, free speech and assembly. The right to family life, the protection of children and the right to education are contained in Art. 41, Art. 42 and Art. 42A. Freedom of religion is also protected. $^{5}$

While the Constitution is often unfavourably - and, in many respects, quite unfairly - compared with the European Convention on Human Rights (ECHR) by political activists and non-governmental organisations, it has nonetheless succeeded in becoming a key part of the political debate and is increasingly seen as a badge of national identity. In many respects its longevity and the vast corpus of important case law thereby generated, along with the fact that it can only be amended by referendum, have all contributed to this development.

\subsection{The Amendment of the Constitution in Relation to the European Union}

1.2.1-1.2.4 As is by now (relatively) well known, the Irish rules governing the transfer or delegation of powers to the European Union are complicated and, in many respects, quite singular. While the recent decision in Pringle v. Government of Ireland $^{6}$ has in some respects presaged a significant change in direction, in practice every significant treaty change over the last forty years or so has had to be enacted by referendum. Why is this so?

The Constitution of Ireland of 1937 is relatively 'rigid' in that since June 1941 it can only be amended by means of a referendum. If, therefore, it is considered that the ratification of an EU Treaty requires a constitutional amendment, then this can be achieved only by means of a referendum. Articles 46 and 47 of the Constitution require that a special Bill must be passed in both Houses of the Oireachtas (Parliament). The Bill must then be submitted to referendum and the amendment is carried if a simple majority vote in its favour. The Constitution has been amended in this manner on 29 occasions, but there have also been 11 occasions where such a proposal has been defeated. The referendum procedure is regarded as the

\footnotetext{
${ }^{5}$ See generally Kelly 2003; and Casey 2000.

${ }^{6}$ [2012] IESC 47, [2013] 3 IR 1.
} 
quintessence of the overriding principle contained in the Constitution itself, namely that of popular sovereignty. ${ }^{7}$ The Supreme Court has twice rejected the notion that there are implied limits to the capacity of the People to amend the Constitution. ${ }^{8}$

There have been nine referendums in respect of European treaties:

\begin{tabular}{l|l|l}
\hline 1. & 1972 & Entry into the EEC \\
\hline 2. & 1987 & Single European Act \\
\hline 3. & 1992 & Maastricht \\
\hline 4. & 1998 & Amsterdam \\
\hline 5. & 2001 & Nice I (defeated) \\
\hline 6. & 2002 & Nice II (successful) \\
\hline 7. & 2008 & Lisbon I (defeated) \\
\hline 8. & 2009 & Lisbon II (successful) \\
\hline 9. & 2012 & Fiscal Treaty \\
\hline
\end{tabular}

These referendums have led to the inclusion of several constitutional amendments that authorise the ratification of the relevant EU treaties, including the following clauses in Art. 29.4:

$4^{\circ}$ Ireland affirms its commitment to the European Union within which the member states of that Union work together to promote peace, shared values and the well-being of their peoples.

$5^{\circ}$ The State may ratify the Treaty of Lisbon ..., and may be a member of the European Union established by virtue of that Treaty. ...

$7^{\circ}$ The State may exercise the options or discretions -

i to which Article 20 of the Treaty on European Union relating to enhanced cooperation applies,

ii under Protocol No. 19 on the Schengen acquis ..., and

iii under Protocol No. 21 on the position of the United Kingdom and Ireland in respect of the area of freedom, security and justice ...,

but any such exercise shall be subject to the prior approval of both Houses of the Oireachtas.

$8^{\circ}$ The State may agree to the decisions, regulations or other acts -

i under the Treaty on European Union and the Treaty on the Functioning of the European Union authorising the Council of the European Union to act other than by unanimity,

ii under those treaties authorising the adoption of the ordinary legislative procedure, and

iii under subparagraph (d) of Article 82.2, the third subparagraph of Article 83.1 and paragraphs 1 and 4 of Article 86 of the Treaty on the Functioning of the European Union, relating to the area of freedom, security and justice,

but the agreement to any such decision, regulation or act shall be subject to the prior approval of both Houses of the Oireachtas.

\footnotetext{
${ }^{7}$ See Pringle v. Government of Ireland [2012] IESC 47, [2013] 3 IR 1, 101-103 per O'Donnell J.

${ }^{8}$ Re Art. 26 and the Regulation of Information Bill 1995 [1995] 1 IR 1, Riordan v. An Taoiseach.
} 
$9^{\circ}$ The State shall not adopt a decision taken by the European Council to establish a common defence pursuant to Article 42 of the Treaty on European Union where that common defence would include the State.

$10^{\circ}$ The State may ratify the Treaty on Stability, Coordination and Governance in the Economic and Monetary Union ....?

The Constitution is, of course, the quintessential product of orthodox nationalist thinking about the nation state. It proceeds on the assumption that state sovereignty resides in one of the three organs of state, namely, the executive, legislative and judiciary. Thus, even to this day, Art. 15.2.1 of the Constitution makes the following claim that:

The sole and exclusive power of making laws for the State is hereby vested in the Oireachtas [Parliament]: no other legislative authority has power to make laws for the State.

This latter claim is, of course, quite unrealistic in the context of EU membership, but broadly similar claims are also made in the context of both the executive and judicial powers. How, then, can these constitutional provisions be reconciled with EU membership? The short answer is that they cannot in themselves be so reconciled.

Faced with this problem on entry to the (then) EEC in 1972, the device was adopted by the Third Amendment of the Constitution Act 1972, whereby Art. 29 of the Constitution, which deals with international relations, was amended to permit entry. The effect of this general amendment, ${ }^{10}$ which was expressed to override all other constitutional provisions, was that (a) Ireland was empowered to join the European Economic Community, and (b) no law or administrative act which was 'necessitated' by Ireland's Community law obligations could be found unconstitutional ('the necessitated obligations' clause). The 'necessitated obligations' clause, now contained in Art. 29.4.6, provides as follows:

$6^{\circ}$ No provision of this Constitution invalidates laws enacted, acts done or measures adopted by the State, before, on or after the entry into force of the Treaty of Lisbon, that are necessitated by the obligations of membership of the European Union ..., or prevents laws enacted, acts done or measures adopted by -

\footnotetext{
${ }^{9}$ For the text of the Constitution, see http://www.irishstatutebook.ie/eli/cons/en.

${ }^{10}$ Originally numbered as Art. 29.4.3. It has subsequently been renumbered on several occasions to accommodate a variety of constitutional amendments. Following on the 28th Amendment of the Constitution Act 2009 (which permitted the ratification of the Lisbon Treaty), it is now numbered as Art. 29.4.6. A version of the 'necessitated obligations' clause in relation to legislation enacted pursuant to obligations imposed by the Fiscal Treaty is contained in Art. 29.4.10 following the enactment of the 30th Amendment of the Constitution Act 2012 (which permitted the ratification of the Fiscal Treaty).
} 
i the said European Union ... institutions thereof,

ii the European Communities or European Union existing immediately before the entry into force of the Treaty of Lisbon, or institutions thereof, or

iii bodies competent under the treaties referred to in this section, from having the force of law in the State.

The formula contained in what was then Art. 29.4.3 of the Constitution worked relatively well until its limitations were highlighted by the Supreme Court's decision in April 1987 in Crotty v. An Taoiseach. ${ }^{11}$ The plaintiff in this case had challenged the decision of the Government to ratify the Single European Act (SEA) by means of parliamentary legislation only, without a referendum. The Supreme Court ultimately held that ratification of Title II of the SEA (dealing with the creation of the single market) was within the scope of the 1972 constitutional amendment, since it did no more than attempted to give effect to market integration policies which had been contained in the original 1957 EC Treaty. The Court took a different view of Title III (which provided for formalised common foreign policies rules), holding that a constitutional amendment was necessary to ratify this aspect of the Treaty.

The Supreme Court's reasoning may be summarised thus:

(a) There was no Community legal - as distinct from political - obligation to ratify the SEA. Ratification by parliamentary legislation was therefore not protected from constitutional attack by the 'necessitated obligations' clause in the 1972 amendment.

(b) Without the protection of the 'necessitated obligations' clause, ratification was unconstitutional, since Title III of the SEA curbed an essential feature of state sovereignty. In the Court's view the power to conduct the foreign affairs of the state was an essential part of sovereignty, and the Government could not by a binding Treaty commitment agree to transfer that power to other states or to the Community.

While the reasoning and ultimate decision in Crotty remain controversial, it has been nonetheless accepted by successive Governments of the day. A special referendum was then passed in May $1987^{12}$ allowing ratification of the Single European Act. But the long-term implications have also been significant. In practice, this means that the ratification of every Treaty change involving any further appreciable transfer of sovereignty or the creation of new competences for the Union has required - or at least has been thought to require - a referendum. ${ }^{13}$

\footnotetext{
${ }^{11}$ [1987] IR 713. ('An Taoiseach' are the Irish words for 'the Prime Minister'). For the background to this important decision and its implications, see generally, Hogan 1987; Bradley 1987; and Temple Lang 1987.

12 10th Amendment of the Constitution Act 1987.

${ }^{13}$ Of course, there have been several instances where Ireland has ratified Treaty changes without the necessity for a constitutional amendment, not least in the case of Treaty changes required to permit accession by new Member States.
} 
One of the difficulties with Crotty is that it is a single, isolated judgment from the Supreme Court which is by now over twenty-five years old. Not surprisingly, the composition of that Court has changed completely in the intervening years. Moreover, both Irish constitutional law and European Union law have developed significantly in the last thirty years.

A more nuanced view emerged from the Supreme Court's decision in Pringle v. Government of Ireland. ${ }^{14}$ In Pringle, the plaintiff's case was that the ratification of the European Stability Mechanism Treaty was such a momentous decision on the part of the Government that, following Crotty, it required approval by a referendum. The plaintiff pointed to the fact that it involved a potential liability of up to 11.1454 billion EUR by way of contribution to a fund totalling some 700 billion EUR for the express purpose of securing the stability of the eurozone in circumstances where the allocations from the fund could, at least in certain circumstances, be made by a qualified majority of the contracting states, which might not include Ireland, either because Ireland disagreed with the allocation or was excluded from voting.

O'Donnell J. put the matter well when he stated:

There can be little doubt that if the essence of sovereignty, at least as contemplated by the Irish Constitution, is to be understood as meaning that Ireland fetters its sovereign right to decide by joining any organisation which acts collectively, or at least one in which Ireland does not retain a veto (and therefore the right to say no), then the ESM Treaty would be of dubious constitutional validity, along with, it must be said, many other important international agreements. ${ }^{15}$

Following a very close analysis of the relevant provisions of Art. 28 and Art. 29 of the Constitution dealing with executive responsibility to Dáil Éireann (the lower House of Parliament) and the executive's powers in the field of foreign affairs, respectively, O'Donnell J. went on to point out that

[f]rom these provisions may be drawn the unremarkable conclusion that the Constitution contemplates that the conduct of the State's foreign relations will necessarily involve the making of binding agreements with other states, which agreements could have financial consequences for the State, and on occasions require an alteration of its domestic law. ... It can be deduced from these constitutional provisions, at a minimum, that the Constitution clearly anticipated the Executive power could and would involve the making of binding agreements with other nations, and that Ireland might become involved in disputes which themselves might be resolved by a process involving a binding determination by which Ireland would be obliged to abide. ... This again contemplates that the business of the conduct of foreign affairs might necessarily involve the making of agreements with foreign States, cooperation with, and membership of, international bodies, and occasionally, and regrettably, the possible occurrence of disputes including the commitment of the State to a war.

O'Donnell J. then stressed the extent to which judicial review of the executive function in the sphere of foreign affairs remained limited:

${ }^{14}$ [2012] IESC 47, [2013] 3 IR 1.

15 [2013] 3 IR 1, 104. 
The courts' function in this regard is to enforce those boundaries of, and limitations to, the exercise of the Executive power in foreign relations which are either express in, or to be implied from, the constitutional text, and at the same time to reject any attempt to impose limitations on Governmental conduct of foreign relations not justified by the Constitution.

... Since it is to the Government alone that the conduct of foreign affairs is consigned by the Constitution, it follows that such international relations must be conducted by the Government, which cannot abdicate, alienate, transfer or subordinate its functions to any other State or body.

O'Donnell J. stressed the extent to which membership of international organisations - such as, for example, the United Nations or the International Monetary Fund - was regarded as the very exercise of sovereignty and not a restriction upon its exercise. What was critical, therefore, was whether the power to conduct foreign affairs had been transferred or alienated to another body. Short of that, the fact that the Government had made a momentous decision with potentially profound consequences was in itself irrelevant.

It is hard to disagree with the conclusion of many observers that the effect of Pringle has been to neutralise at least part of the earlier decision in Crotty, which dealt with restrictions on the executive power of the state. ${ }^{16}$ One should not, however, deduce from this that the Government now has a free hand, because the other aspect of Crotty - namely, that a proposal to amend an EU treaty does not enjoy constitutional immunity for the purposes of Art. 29.4.6 of the Constitution because it is not (yet) an obligation of EU law - continues to hold sway. There will thus continue to be constitutional objections where an EU Treaty imposes specific obligations on Member States over and above any perceived restrictions on the right to conduct foreign policy. Accordingly, even if the decision in Pringle had been delivered before the dates of both the Lisbon Treaty and the Fiscal and Stability Treaty, it is hard to see how a referendum would still not have been required in both instances. In the case of the Lisbon Treaty, the decision to accord Treaty status to the Charter of Fundamental Rights would probably have required a constitutional amendment, given the uncertain reach and scope of the Charter and the manner in which it might potentially overreach some of the corresponding fundamental rights provisions of the Irish Constitution. The same is true in respect of the Fiscal Treaty: the specific obligations in relation to fiscal discipline and budget deficits would cut across the autonomy of Dáil Éireann in relation to such matters granted by the Constitution.

The provisions of Art. 29.4.7 and Art. 29.4.8 have their origins in the variable geometry provided for in the aftermath of the Amsterdam Treaty. Given that the United Kingdom had secured opt-outs from the Schengen agreement and in the entire area of justice and home affairs, it was for practical purposes necessary for Ireland to do likewise, as otherwise the entire common travel arrangements with the United Kingdom (and specifically free access over the land border with Northern Ireland) would have been placed in jeopardy. From a constitutional perspective it

\footnotetext{
${ }^{16}$ See in particular the important articles written by two former members of the Supreme Court: Keane 2014, pp. 195-213; and Geoghegan 2014, pp. 213-219.
} 
was considered that the 'necessitated obligations' clause would break down in the face of the adoption of measures in respect of which Ireland later elected to opt in and which were thus plainly optional in the sense just described. Article 29.4.7 and Art. 29.4.8 are accordingly designed to give democratic legitimacy to such decisions by securing the prior assent of both Houses of the Oireachtas. In practice, however, this generally amounts to giving parliamentary assent to matters which have already been diplomatically agreed in principle at EU level, and there is no real sense in which the negotiating hand of the executive has been constrained by the need to secure subsequent parliamentary approval.

\subsection{The Supremacy of EU Law}

1.3.1-1.3.4 The constitutional provisions and court judgments regarding sovereignty are outlined in the preceding section.

Regarding supremacy, Ireland may be regarded as a classic example of a dualist state on the basis of Art. 29.6 of the Constitution (see Sect. 3.2). However, the situation is very clearly otherwise in the case of European Union law, since the effect of Art. 29.4.6 of the Constitution, the wording of which was provided in the preceding section, is to confer supremacy on EU law over the domestic law and Constitution to the extent that this is necessitated by the obligations of EU membership. To date, application of the supremacy clause has been largely unproblematic. It is nonetheless clear that from the standpoint of Irish law, EU law is supreme within its proper sphere of application because Art. 29.4.6 of the Constitution says it is, and not because of some autonomous, freestanding notion of European Union law which the Irish courts feel obliged to apply independently of this constitutional provision.

\subsection{Democratic Control}

1.4.1 While Art. 15.2.1 of the Constitution provides that the exclusive lawmaking power resides in the Oireachtas, ${ }^{17}$ it has on the whole performed poorly as a law making institution. In practice, legislation is drafted by specialist teams within the Attorney General's Office, who in turn take their instructions from the civil service departments that sponsor the measure. Very few measures which have been drafted or prepared otherwise than with the approval of the Government become law. To

\footnotetext{
${ }^{17}$ I.e., the Parliament which consists of Dáil Éireann (the lower House), Seanad Éireann (the upper House) and the President.
} 
that extent, therefore, the Oireachtas might better be regarded as 'a law-declaring rather than a law-making body'. ${ }^{18}$

Added to this is the fact that, at least in the past, legislation was often drafted in wide and loose terms, such that in many instances the underlying policy was really to be found in the statutory instrument giving effect to the legislation. Admittedly, Art. 15.2.1 of the Constitution has been deployed on a number of occasions to invalidate legislation which has been held to confer open-ended powers on members of the Government (and, in some cases, other bodies) to make ministerial orders on the basis that the powers so delegated were essentially legislative in nature. ${ }^{19}$ This important development notwithstanding, the basic problem remains that of weak parliamentary oversight of the legislative drafting process.

This problem was especially acute in the context of the transposition of European Union directives, as the European Communities (Amendment) Act 1973 permitted the relevant minister to give effect to a directive by means of a statutory instrument. In essence, the weak parliamentary oversight at Union level ${ }^{20}$ was magnified by even weaker legislative scrutiny at national level, so that important legislative measures are transposed into national law without really any effective parliamentary scrutiny at all. The constitutionality of this system was upheld by the Supreme Court in Meagher v. Minister for Agriculture ${ }^{21}$ and Maher v. Minister for Agriculture $^{22}$ with few, if any, reservations in respect of its implications for a democratic system of government.

The present system can, however, be defended on the very practical ground that it ensures that directives are transposed into national law in a timely fashion:

The ever-increasing number of directives requiring implementation within strict deadlines inevitably puts pressure on members of the Irish executive to implement directives by statutory instruments even in circumstances where enactment by statute might otherwise have been more appropriate. ${ }^{23}$

A key limitation on the power to implement Union law by regulation was contained in Sect. 3(3) of the European Communities Act 1972: an indictable offence may not be created by regulation. However, apparently sensible - and eminently justifiable - judicial intervention here, aimed at upholding the rule of law, has had unforeseen consequences. The issue arose in Browne v. Attorney General, ${ }^{24}$ where the applicant had been charged with violating a ministerial order

\footnotetext{
${ }^{18}$ Chubb 1974, p. 65.

${ }^{19}$ See, e.g., McGowan v. Labour Court [2013] IESC 21, [2013] 2 ILRM 376, Bederev v. Ireland [2015] IECA 38, [2015] 1 ILRM 301.

${ }^{20}$ Even if post-Lisbon the power of co-decision at European Parliament level has been strengthened and enhanced.

${ }^{21}$ [1994] 1 IR 329. See generally Fahey 2010, pp. 51-69 for a very helpful overview of the case law.

22 [2001] 2 IR 139.

${ }^{23}$ Tomkin 2004, p. 150.

24 [2003] 3 IR 205.
} 
which restricted drift-net fishing. The restriction was required by a Council regulation. Indeed, the ministerial order had expressly recited that it was being promulgated in order to permit the enforcement of a Council regulation. In order to circumvent the prohibition in the 1972 Act, the respondent claimed that he possessed the authority to create an indictable offence under Sect. 223A of the Fisheries (Consolidation) Act 1959 (as amended), under which he could 'prescribe and adopt either or both of the following measures, namely, measures of conservation of fish stocks and measures of rational exploitation of fisheries'. The Supreme Court held that the power to make regulations could not be used to circumvent this statutory prohibition:

There is no indication whatever in the language of section 223A that it was envisaged by the Oireachtas that the second respondent could give effect to principles and policies which had never been considered or adopted by the Oireachtas by means of a statutory instrument under that section which effectively circumvented the prohibition on the creation of indictable offences in section 3(3) of the Act of $1972 .{ }^{25}$

The effect of Browne was reversed by the European Communities Act 2007, in which the Oireachtas permitted the creation of indictable offences by secondary legislation implementing Community law. ${ }^{26}$ Section 4 of the 2007 Act also allows the minister to exercise the power to make a statutory instrument for the purposes of implementing an EU act, if the 'obligations imposed on the State under the European act concerned relate, in whole, to matters to which that [power] relates'. Other legislative innovations increasing the armoury of the executive in Community law matters have followed. For example, Sect. 4 of the Communication Regulations (Amendment) Act 2007 inserted a new Sect. 46A into the Communication Regulations Act 2002, which now allows the minister to create indictable offences by regulation in order to give effect to various provisions of Community law. Thus, worries about the democratic deficit aside, an unfortunate and entirely unforeseen - consequence of the Supreme Court decision in Browne has been that instead of compelling the Oireachtas to introduce new criminal offences by primary legislation with the full panoply of political safeguards, there has been an increase in the number of areas in which a minister can introduce new indictable offences by regulation. The requirement of the rule of law that statutory requirements be public and precise has been undermined somewhat by these developments. ${ }^{27}$

In addition, the principle of legal certainty, central to the rule of law, has been undermined by the sheer volume of Community law that is put on the statute books:

\footnotetext{
${ }^{25}$ Ibid., p. 220, per Keane C.J.

${ }^{26}$ European Communities Act 1972, s. 3(3), as substituted by European Communities Act 2007, Sect. 2 .

${ }^{27}$ Cf. Quinn v. Ireland [2007] IESC 16, [2007] 3 IR 395, where Denham J. held that regulations having statutory effect (Sect. 4 of the European Communities Act 1972 having given birth to such strange creatures) cannot themselves be amended by subsequent regulations.
} 
There is no official publication that gives up to date information as to whether or not a particular statutory instrument has been amended or revoked. In fact, the only certain way of establishing as to whether or not a particular statutory instrument is in force, is by going through every subsequent statutory instrument manually, and checking to see if another statutory instrument under a different name, amends the earlier statutory instrument. ${ }^{28}$

1.4.2 On EU referendums in Ireland, see Sect. 1.2.

\subsection{Waning Constitutional Influence?}

1.5.1-1.5.3 While concerns have been frequently expressed that the on-going expansion of the scope and reach of European Union law might ultimately lead to a waning of the influence of the Constitution of Ireland, this has not (as yet, at least) happened. These concerns were particularly voiced during the two Lisbon referendums, as it was suggested that by 'constitutionalising' the Charter of Fundamental Rights and by the ever expanding potential reach of EU law, key decision-making on aspects of fundamental rights by the Irish judiciary (and especially by the Irish Supreme Court) might be supplanted in practice by the Court of Justice.

It has to be said that there is no immediate sign of this, partly because of the absolute centrality of the Constitution to Irish political, social and legal discourse. In addition, the fact that the People have an important role in key decision-making via the referendum process reinforces this legal and cultural tendency. This was immediately visible in the recent same-sex marriage referendum on 22 May 2015. The striking scenes of popular joy and celebration in Dublin as the referendum results were announced were remarkable, even astonishing. ${ }^{29}$ While some disagree as to the wisdom of the referendum process in relation to matters of this kind, ${ }^{30}$ what is undeniable is that a decision of this sensitivity brought about in this fashion is likely to have greater long-term democratic acceptability even by comparison with a purely legislative change or a change imposed by either the Irish Supreme Court, the Court of Justice or the European Court of Human Rights.

\footnotetext{
28 Tomkin 2004, p. 152.

${ }^{29}$ See e.g. O'Hanlon, G (2015, June 1) Scenes of joy in Dublin Castle on May 23rd felt like a kind of secular Pentecost. The Irish Times.

${ }^{30}$ See e.g. Weeks, L. (2015, June 2). Rule by way of referendum is not the best way to make decisions. The Irish Times.
} 


\section{Constitutional Rights, the Rule of Law and EU Law}

\subsection{The Position of Constitutional Rights and the Rule of Law in the Constitution}

2.1.1 Articles 40 to 44 of the Constitution of Ireland are headed 'Fundamental Rights' and deal with what might be regarded as standard civil and political rights: thus the principle of equality, life, person, good name, property rights, personal liberty, habeas corpus, inviolability of the dwelling, free speech and assembly, family and children, education and freedom of religion are all protected. In addition, Art. 38.1 of the Constitution guarantees that '[n]o person shall be tried on any criminal charge save in due course of law', and Art. 38.5 guarantees the right to jury trial. In some cases the guarantees are detailed and specific: this is true, for example, of the procedure to be followed in habeas corpus applications. ${ }^{31}$ In most other cases, however, the guarantees are expressed at a high level of generality. ${ }^{32}$

Two specific features of these fundamental rights provisions should, however, be noted. First, the courts have developed a doctrine of unenumerated or implied rights designed to capture standard fundamental rights which are not otherwise expressly provided for in Arts. 40 to 44: rights protected under this heading include free movement and travel, the right to fair procedures, the right to marry and the right to privacy. Secondly, Art. 45 contains a list of what would nowadays be described as socio-economic rights which are not 'cognisable by any Court under any provision of this Constitution'. 33

Over and above the specific constitutional provisions lie the general principles of law - such as proportionality, non-retroactivity and legal certainty - some of which have a specific constitutional grounding. Thus, for example, Art. 5 of the Constitution describes the State as a democracy, and this provision is increasingly cited by the courts to justify decisions supporting the rule of law. ${ }^{34}$ Article 15.5.1

\footnotetext{
${ }^{31}$ Article 40.4.1 provides that '[n]o citizen shall be deprived of his personal liberty save in accordance with law'. Para. 2 continues as follows: 'Upon complaint being made by or on behalf of any person to the High Court or any judge thereof alleging that such person is being unlawfully detained, the High Court and any and every judge thereof to whom such complaint is made shall forthwith enquire into the said complaint ... and the High Court shall ... after giving the person in whose custody he is detained an opportunity of justifying the detention, order the release of such person from such detention unless satisfied that he is being detained in accordance with the law.' 32 Thus, for example, Art. 40.5 provides: 'The dwelling of every citizen is inviolable and shall not be entered save in accordance with law.'

${ }^{33}$ Thus, for example, Art. 45.4.2 provides: 'The State shall endeavour to ensure that the strength and health of workers, men and women, and the tender age of children shall not be abused and the citizens shall not be forced by economic necessity to enter avocations unsuited to their sex, age or strength.'

${ }^{34}$ See e.g. Mallak v. Minister for Justice [2012] IESC 59 (The Minister does not enjoy an absolute discretion with regard to a naturalisation application if by this is meant that he or she is free to act in an autocratic or arbitrary fashion, since this would be the antithesis of the guarantee contained in Art. 5); Waterville Fisheries Development Ltd v. Acquaculture Licensing Appeals Board (No.2)
} 
expressly forbids the enactment of legislation 'which declare[s] acts to be infringements of the law which were not so at the date of their commission'.

2.1.2 The Constitution itself uses different language to describe the rights it protects and sometimes employs different language to set out the circumstances in which the right can be curtailed or restricted. Although some rights are described as 'inviolable' or 'inalienable', this is not universally the case. Similarly, while the power of the State 'to delimit the exercise of constitutionally protected rights' is expressly given in some cases and not referred to at all in others, this does not mean 'that, where absent, the power does not exist'. ${ }^{35}$

For the best part of twenty years, however, the Irish courts have employed a standard proportionality doctrine in assessing the validity of legislative restrictions on the exercise of constitutional rights. The classic test remains that articulated by Costello J. in Heaney v. Ireland: ${ }^{36}$

The objective of the impugned provision must be of sufficient importance to warrant overriding a constitutionally protected right. It must relate to concerns pressing and substantial in a free and democratic society. The means chosen must pass a proportionality test. They must:

(a) be rationally connected to the objective and not be arbitrary, unfair or based on irrational considerations,

(b) impair the right as little as possible, and

(c) be such that their effects on rights are proportional to the objective.

This test has been consistently applied and it has helped to provide an objective template whereby the legitimacy of such restrictions on the exercise of constitutional rights can be assessed. ${ }^{37}$

2.1.3 Irish courts frequently employ the concept of the rule of law, although this is sometimes no more than a rhetorical makeweight. Nevertheless, the rule of law principles reflect the idea that the State is described as a democracy in Art. 5 of the Constitution and that Art. 34 of the Constitution commits the administration of justice to the judiciary. Among the key ideas contained in the rule of law decision making found in the Irish jurisprudence are the following:

- The principle of legality: every decision affecting legal rights must have an appropriate legal basis.

[2014] IEHC 381 ('absolute discretion' given by statute does not mean that the Board was not obliged to give reasons for its decisions).

${ }^{35}$ Murray v. Ireland [1985] IR 532, 538, per Costello J.

36 [1994] 3 IR 593, 607, per Costello J. The test was expressly borrowed from a then contemporary decision of the Supreme Court of Canada: Chaulk v. R. (1990)3 SCR 1335-1336.

${ }^{37}$ See, e.g., Daly v. Revenue Commissioners [1996] 3 IR 1 Re Art. 26 and the Health (Amendment) Bill (No.2) [2005] IESC 7, [2005] 1 IR 105, King v. Minister for Environment (No.2) [2006] IESC 61, [2007] 2 IR 296. See generally: Hogan 1997, Foley 2010 and Kenny 2014. 
- The executive cannot constitutionally be given the power by statute to act in an arbitrary or autocratic fashion. ${ }^{38}$

- The right of access to the courts: legislation which restricts the right of access to the courts will be construed narrowly. ${ }^{39}$ Legislation which unfairly restricts access to the courts will be found to be unconstitutional. ${ }^{40}$

- The law must be certain and accessible. ${ }^{41}$

- Legislation cannot retroactively create new criminal offences or other legal wrongs. ${ }^{42}$

- Fundamental rights should not be affected adversely by legislation save through the use of clear language. ${ }^{43}$

- Legal penalties cannot be created by the use of oblique language in a statute. It is, for example, a 'cardinal principle in the judicial interpretation of statutes that the range of criminal liability should not be held to have been statutorily extended except by clear, direct and unambiguous words'. ${ }^{44}$

\footnotetext{
${ }^{38}$ Mallak v. Minister for Justice [2012] IESC 59; Waterville Fisheries Development Ltd. v. Acquaculture Licensing Appeals Board (No.2) [2014] IEHC 381.

${ }^{39}$ Murphy v. Greene [1990] 2 IR 560, Re MJBCH [2013] IEHC 256, [2013] 1 IR 407.

${ }^{40}$ Macauley v. Minister for Posts and Telegraphs [1966] IR 345, Blehein v. Minister for Health and Children [2008] IESC 40, [2009] 1 IR 275.

${ }^{41}$ But note the decision of the Supreme Court in Minister for Justice and Equality v. Adach [2010] IESC 33, [2010] 3 IR 402. The background to that case was that the European Arrest Warrant Act 2003 had been amended by legislation enacted by the Oireachtas (Parliament) and duly signed by the President on 21 July 2009. Notice of this had been published in the official gazette in the manner required by Art. 25 of the Constitution. The amending legislation required that no appeal would be taken in European Arrest Warrant cases save with leave of the High Court. In October 2009 the requested person, Mr. Adach, purported to appeal without leave of the High Court, contending that the new legislation had not been officially published until November 2009. This was admitted - a translation into Irish had been awaited - but the Supreme Court noted that the appellant and his advisers were fully aware of the effect of the new provision and they had been advised of its terms by the trial judge. The Court rejected arguments that case law such as Case C-345/06 Heinrich [2009] ECR I-01659 had any relevance to this question, since the matter was governed entirely by the publication requirements of Art. 25 of the Constitution. While Hardiman J. acknowledged the importance 'of accessibility, clarity and foreseeability when considering laws mandating the deprivation of a person's liberty', this was not such a case, as the legislation in question was essentially a law prescribing new procedural rules.

${ }^{42}$ Doyle v. An Taoiseach [1986] ILRM 693. See also The People v. Geraghty [2014] IECA 2.

${ }^{43}$ See e.g. Albatross Feeds Ltd v. Minister for Agriculture and Food [2006] IESC 52, [2007] 1 IR 271.

${ }^{44}$ Director of Public Prosecutions v. Flanagan [1979] IR 265, 280 per Henchy J. Additionally, laws which create unclear or arbitrary offences have been held to be unconstitutional: see, e.g., King v. Director of Public Prosecutions [1981] IR 233, Douglas v. Director of Public Prosecutions [2013] IEHC 343, [2014] 1 IR 510.
} 


\subsection{The Balancing of Fundamental Rights and Economic Freedoms in EU Law}

2.2.1 During the referendums on the Lisbon Treaty, certain decisions of the Court of Justice of the European Union (CJEU), such as Laval and Viking, ${ }^{45}$ prompted concerns about the EU prioritising economic liberties over traditional human rights, and that the CJEU imposed significant limitations on the right of workers to take collective action where the exercise of that right interfered with the freedom of establishment and freedom to provide services. ${ }^{46}$ This issue has, however, simply not arisen in practice, and it remains to be seen how the Irish courts would endeavour to reconcile traditional liberties with the free movement objectives which were prioritised in Laval and Viking.

\subsection{Constitutional Rights, the European Arrest Warrant and EU Criminal Law}

Introduction: Implementation of the European Arrest Warrant (EAW) in Ireland and the main principles in its judicial application The European Arrest Warrant Act 2003 (as amended) (the 2003 Act) has given effect to the EAW Framework Decision. ${ }^{47,48}$ The system mandated by the 2003 Act requires that all applications be made to the High Court, generally under the supervision of a specially assigned judge. Since 2009, leave is required before an appeal can be taken from the High Court to the Supreme Court. ${ }^{49}$ Following the establishment of the new Court of Appeal in October 2014, appeals now lie (with leave) to the Court of Appeal. In exceptional cases the Supreme Court can grant leave to hear an appeal from the Court of Appeal.

A further consideration is that prior to 1 December 2014, no Irish court had jurisdiction to make a reference to the CJEU in respect of the interpretation of a framework decision. Article 10(3) of Protocol No. 36 to the Treaty of Lisbon provided for jurisdiction to make a reference after a five-year transitional period. The Lisbon Treaty entered into force on 1 December 2009, and the transitional period expired on 1 December 2014. Given the sheer volume of case law which the

\footnotetext{
45 Case C-341/05 Laval [2007] ECR I-11767 and Case C-438/05 Viking Line [2007] ECR I-10779.

46 Kiernan et al. 2012, p. 539.

${ }^{47}$ Council Framework Decision of 13 June 2002 on the European arrest warrant and the surrender procedures between Member States (2002/584/JHA), [2002] OJ L 190/1.

48 See generally, Fahey 2010, pp. 107-128 and more generally, Farrell and Hanrahan 2011.

49 Section 16(11) of the 2003 Act (as substituted by Sect. 10 of the EAW (Application to Third Countries and Amendment) and Extradition (Amendment) Act 2012).
} 
2003 Act has generated to date, ${ }^{50}$ one may expect - should this trend continue that a steady stream of references will be made by the Irish courts over the next number of years.

Indeed, this case law has been such that it could not be said that the Irish courts have largely acted as 'rubber stamps', since the Irish courts have paid particular attention to the procedural safeguards prescribed by the 2003 Act. Accordingly, applications for surrender which have not specified with 'unambiguous clarity ... the number and nature of the offences for which the person sought is so sought ${ }^{51}$ or have not clearly indicated whether the warrant sought is in respect of a conviction in absentia $^{52}$ will be rejected. There is likewise no prospect of surrender if the foreign offence does not 'correspond' to an offence known to Irish law. ${ }^{53}$ The High Court has nonetheless provided a very complete explanation of the difference between the EAW system and the former system of extradition in O'Sullivan v. Irish Prison Service, ${ }^{54}$ which admirably sums up the prevailing judicial attitude to the EAW regime:

Despite superficial similarities between extradition and surrender, namely that both can result in the forcible departure, by compulsion of law, of a person from this State, the EAW regime must be considered as a regime different, separate and distinct from extradition. The principles upon which each rests are materially different: one driven by executive motivation, the other by mutual judicial trust and respect. The EAW regime was developed to solve many notable and renowned problems, which developed with the extradition system which existed previously. The former regime, and indeed the one which still regulates our relationship with the vast majority of States worldwide, was technical, slow, and lacked reciprocal judicial trust and respect. Without the latter it is incumbent on both the State and its Courts to apply a heightened level of scrutiny in relation to those being extradited; many of the world's legal systems do not uphold the same principles or rule of law or democracy which we enjoy here, the risk of wrongful conviction or mala fides prosecution are therefore much greater outside of the EU. Even with our more developed neighbours, procedural safeguards and concepts of justice and punishment may be at significant variance with our own. A more thorough investigative procedure is therefore both justified and required, so as to safeguard the rights of those whose extradition is sought ... .

The EAW regime and the Framework Decision upon which it is based are the result of ever-increasing cooperation in criminal and judicial matters, particularly with regards to extradition ... within the Union, which was necessitated by the opening up of the free market. ... This has meant the removal of a number of traditional exceptions for extradition, for example with regards to the political offence exception and the non-extradition of nationals.

\footnotetext{
${ }^{50}$ The Supreme Court appears to have given some 40 written judgments on diverse aspects of the EAW.

${ }^{51}$ Minister for Justice and Equality v. Connolly [2014] IESC 34, [2014] 2 ILRM 241, 253, per Hardiman J.

52 Minister for Justice and Equality v. Palonka [2015] IECA 69.

53 2003, Sect. 38(1)(b) and see generally Minister for Justice and Equality v. Marjasz. [2012] IEHC 233. Differences in terminology between domestic and foreign offences do not, however, generally lead to a lack of correspondence: see Minister for Justice v. Szall [2013] IESC 7, [2013] 1 IR 470.

${ }^{54}$ [2010] 4 IR 562.
} 
Therefore it cannot be accurate to assimilate, ideologically or practically, the case law or mind-set of extradition into those of intra-Union surrender. ... I am satisfied that this represents an entirely new system. Surrender is not extradition. There is no hearing into the merits of the prosecution, pending or anticipated in the requesting jurisdiction; nor should there be; and the Executive no longer has a role. There is a special relationship between the Member States of the Union. By virtue of this unity there is increased judicial co-operation between Members. However there is necessarily a great level of trust that the other Member State will act in accordance with the highest and fundamental principles of the Union; namely rule of law, peace, freedom and democracy. Nonetheless, there may be circumstances where certain Member States may be lacking in this regard. It is for this reason that procedural safeguards are placed within the Framework Decision. ${ }^{55}$

In addition, as will be seen, some hugely complicated EAW cases have come before the Irish courts. Two in particular - Minister for Justice v. Tobin and Minister for Justice v. Bailey - require elaborate consideration. But before examining this case law, a number of special features and safeguards of the 2003 Act should be noted.

First, Sect. 38 of the 2003 Act contains important safeguards in terms of the correspondence of the offence and the seriousness of the offence. Section 38(1)(b) of the 2003 Act provides:

Subject to subsection (2), a person shall not be surrendered to an issuing state under this Act in respect of an offence unless (a) the offence corresponds to an offence under the law of the State, and

(i) under the law of the issuing state the offence is punishable by imprisonment or detention for a maximum period of not less than 12 months, or

(ii) a term of imprisonment or detention of not less than 4 months has been imposed on the person in respect of the offence in the issuing state, and the person is required under the law of the issuing state to serve all or part of that term of imprisonment or (a) the offence is an offence to which paragraph 2 of Article 2 of the Framework Decision applies or is an offence that consists of conduct specified in that paragraph, and under the law of the issuing state the offence is punishable by imprisonment for a maximum period of not less than 3 years.

Secondly, the provisions of Sect. 37 include the following safeguards that will be of importance to the cases that follow:

(1) A person shall not be surrendered under this Act if:

(i) $\ldots$

(a) his or her surrender would constitute a contravention of any provision of the Constitution (other than for the reason that the offence specified in the European arrest warrant is an offence to which section $38(1)(b)$ applies $^{56}$ ),

\footnotetext{
55 [2010] 2 IR 562 at 597-598, per McKechnie J.

${ }^{56}$ This is a technical provision to ensure that applicants cannot resist extradition on the ground that they would be deprived of their right to jury trial for serious offences punishable for more than one year in the requesting state.
} 
(b) there are reasonable grounds for believing that:

(i) ...

(ii) in the prosecution or punishment of the person in the issuing state, he or she will be treated less favourably than a person who:

(I) is not his or her sex, race, religion, nationality or ethnic origin,

(II) does not hold the same political opinions as him or her,

(III) speaks a different language than he or she does, or

(IV) does not have the same sexual orientation as he or she does,

or

(ii) were the person to be surrendered to the issuing state:

(I) he or she would be sentenced to death, or a death sentence imposed on him or her would be carried out, or

(II) he or she would be tortured or subjected to other inhuman or degrading treatment.

Section 37 of the 2003 Act may be thus be said to give effect to Recital 12 of the Framework Decision, which provides that the EAW procedure does not:

[p]revent a Member State from applying its own constitutional rules relating to due process, freedom of association, freedom of the press and freedom of expression in other media.

In fact, Sect. 37 of the 2003 Act probably goes a good deal further than this by protecting the full panoply of constitutional rights and not just those reflecting due process and freedom of speech. ${ }^{57}$ In the course of the parliamentary debates on the 2003 Bill, the sponsoring minister justified Sect. 37 of the 2003 Act on the ground that it would ensure that 'no state in the European Union [would] have a higher degree of real and substantial protection for those who seek the protection of the [Irish] courts'. 58

It is perhaps not altogether surprising that these provisions have generated a good deal of case law. While it might seem that the Irish courts are under a particular duty to treat surrender applications under the EAW procedure in 'a most serious fashion', the 'practical operation of the Act of 2003 has not matched the

\footnotetext{
${ }^{57}$ The Commission Staff Report Document, Annex to the Report from the Commission on the implementation since 2005 of the Council Framework Decision of 13 June 2002 on the European arrest warrant and the surrender procedures between Member States (2007), at pp. 5-6 commented adversely on this development:

'... EL, IE, IT and CY have transposed the text into their legislation in such a way that it goes beyond the Framework Decision and therefore creates the risk that a EAW will be refused on the basis of grounds not envisaged in the Framework Decision. In addition to referring to the European Convention on Human Rights, IE and IT require refusal where surrender would breach their national constitutions. Although this may cover situations arising under both Art. 6 TEU and Recital 12 (such as rules on due process), it nevertheless goes beyond the Framework Decision, in particular as Art. 6 TEU refers only to those constitutional principles common to Member States.' 58577 Dáil Debates Col. 10 (17 December 2003).
} 
ideal and the role of Sect. 37 has been "read down" dramatically through judicial interpretation, ${ }^{59}$

In Minister for Justice v. Altaravicius ${ }^{60}$ the Supreme Court stressed that the 2003 Act must be interpreted in the light of the objectives of the Framework Decision, which include 'to remove the complexity and potential for delay inherent' in the pre-existing extradition arrangements between the Member States (Preamble) and to ground the EAW procedure on the principle of mutual recognition of judicial decisions (Recital 6 and Art. 1(2)) and 'on a high level of confidence between Member States' (Recital 10). It was against that background that the Supreme Court stressed that the residual power to refuse surrender contained in Sect. 37(1)(b) of the 2003 Act must be understood: this provision was a residual power which was to be confined to exceptional cases. As Murray C.J. stated, it could not constitute a breach of the Constitution to effect a surrender 'simply because [the foreign] legal system of trial differed from ours as envisaged by the Constitution' ${ }^{61}$

\footnotetext{
${ }^{59}$ Fahey 2010, p. 110. For a similar view, see Walsh 2009.

${ }^{60}$ [2006] IESC 23, [2006] 3 IR 148.

${ }^{61}$ [2007] 3 IR 732, 743. The Chief Justice had earlier stated ([2007] 3 IR 732, 741):
}

'The effect of such an argument is that an order for surrender under the Act of 2003, and indeed any order for extradition, ought to be refused if the manner in which a trial in the requesting State including the manner in which a penal sanction is imposed, does not conform to the exigencies of our Constitution as if such a trial or sentence were to take place in this country. That can hardly have been the intention of the Oireachtas when it adopted s. 37(1) of the Act of 1973 since it would inevitably have the effect of ensuring that most requests for surrender or extradition would have to be refused. And indeed if that were the intent of the Framework Decision ... and other countries applied such a test from their own perspective, few, if any, would extradite to this country .......

The manner, procedure and mechanisms according to which fundamental rights are protected in different countries will vary according to national laws and constitutional traditions. The checks and balances in national systems may vary even though they may have the same objective such as ensuring a fair trial. There may be few, if any, legal systems which wholly comply with the precise exigencies of our Constitution with regard to these matters. Not all for example will provide a right to trial by jury in exactly the same circumstances as our Constitution does in respect of a trial for a non-minor offence. Rules of evidence may differ. The fact that a person would be tried before a judge and jury in this country for a particular offence could not in my view, be a basis for refusing to make an order for surrender solely on the grounds that in the requesting State he or she would not be tried before a jury. ...

That is not by any means to say that a Court, in considering an application for surrender, has no jurisdiction to consider the circumstances where it is established that surrender would lead to a denial of fundamental or human rights. There may well be egregious circumstances such as a clearly established and fundamental defect in the system of justice of a requesting State where a refusal of an application for surrender may be necessary to protect such rights. It would not be appropriate in this case to examine further possible or hypothetical situations where this might arise. The sole matter which I wish to make clear here is that the mere fact that a trial or sentence may take place in a requesting State according to procedures or principles which differ from those which apply, even if constitutionally guaranteed, in relation to a criminal trial in this country does not of itself mean that an application for surrender should be refused pursuant to s. 37(2) of the Act.' 
This trend was continued in the subsequent decision of the Supreme Court in Minister for Justice v. Stapleton. ${ }^{62}$ Here the question was whether the respondent could invoke undue delay as a ground to resist surrender to the UK under Sect. 37 of the 2003 Act. In effect, the argument was that if he were to face trial in Ireland at that time, he could invoke the jurisprudence arising from the due process provisions of Art. 38.1 in order to demonstrate that such trial would infringe his constitutional rights due to undue delay. Proceeding from that premise, the applicant then argued that his surrender to the UK would amount to an infringement of his constitutional rights.

In his judgment for the Supreme Court, Fennelly J. observed that the principle of 'mutual confidence' in the respective legal systems was broader and went further than the systems of mutual political and judicial trust which were contained in the European Convention on Extradition 1957 and, in our own legal system, the Extradition Act 1965, as it 'encompasses the system of trial in the issuing member state'.

Fennelly J. further noted that the question of whether there had been any undue delay could be best resolved within the context of the legal system of the requesting state. The mere fact that there was a difference in criminal procedure between the two jurisdictions was not in itself enough. Fennelly J. then stated:

I cannot see that any of the differences discerned by the trial judge between the right to seek prohibition of trial in the English courts and our own could amount to the establishment of an infringement of the right to fair trial, or fair procedures, whether by reference to the [European] Convention [on Human Rights] or to the Constitution. They certainly do not amount, to repeat the words of Murray C.J. [in Brennan], to 'a clearly established and fundamental defect in the system of justice of [the] requesting State'.

On the facts of this case, there is available to the respondent a procedure which will enable him, on surrender to the issuing Member State to seek a remedy based on the very long period of time which has elapsed since the alleged commission of the offences. Moreover, on the facts of the case, it is demonstrably more efficient and more convenient that those matters be debated before the courts of the country where the respondent is to be tried. The prosecuting and police authorities as well as other witnesses are available to and amenable to the jurisdiction of the courts of that country. Documentary evidence, of the type demanded by the respondent, will be more readily available there. If not, its absence may be more readily explained. There may, in addition, be arguments or points of domestic law, whether based on precedents or otherwise, which the respondent can advantageously argue or rely upon which may not be available to him in this jurisdiction and of which an Irish court might not necessarily be aware. ${ }^{63}$

It is accordingly clear from this case law that Sect. 37(1)(b) of the 2003 Act can only be successfully invoked by a respondent if it can be demonstrated that the very act of surrender would either itself ex facie amount to an unconstitutionality in the circumstances or where the Court, acting on the clearest of evidence, has significant grounds for apprehending that the requested person would, if surrendered, face a

${ }^{62}$ [2007] IESC 30, [2007] 1 IR 669.

63 [2007] 1 IR 669, 691-692. 
manifestly unfair trial which does not meet contemporary minimum standards presupposed by the Framework Decision itself.

There appears to be only two cases where the Court has refused to sanction surrender in the light of the provisions of Sect. 37. In Minister for Justice and Equality v. Nolan, ${ }^{64}$ the requested person was facing surrender to the UK to serve out the balance of a sentence which had been imposed by a British court. Aspects of that particular sentencing regime had already been held by the European Court of Human Rights (ECtHR) to be contrary to Art. 5.1 of the ECHR insofar as it provided for detention beyond the tariff stipulated by the trial judge. ${ }^{65}$ The Supreme Court held that to surrender the applicant in these circumstances would amount to a breach of Sect. 37(1)(a)(i) of the 2003 Act, since it would be contrary to the state's obligations under the ECHR. In effect, therefore, the Court refused the surrender of the respondent where he would be delivered up to complete the balance of a sentence which had been held to be non-ECHR compliant. In the other case, Minister for Justice and Equality v. Rostas, ${ }^{66}$ the High Court refused to sanction the surrender of a Romanian of Roma ethnicity in respect of a conviction for robbery in 1995, where there were clear and detailed reasons to suggest that the conviction represented a miscarriage of justice. ${ }^{67}$

The decision in Tobin and abuse of process The Irish courts have also been obliged to deal with some particularly difficult EAW cases, of which the Tobin litigation is perhaps the paradigm example. In Minister for Justice v. Tobin (No. 1), ${ }^{68}$ an Irish national ${ }^{69}$ had been arrested in Hungary following the death of two young children in a road traffic accident. He was then permitted by the authorities to leave Hungary, but was subsequently convicted in his absence by the Hungarian courts. The Supreme Court ultimately refused to sanction his surrender from Ireland under the EAW procedure on the basis that it had not been shown that he had 'fled' Hungary in the manner then required by Sect. 10 of the 2003 Act.

${ }^{64}$ [2013] IESC 54.

${ }^{65}$ See James, Wells and Lee v. the United Kingdom, nos. 25119/09, 57715/09 and 57877/09, 18 September 2012.

${ }^{66}$ [2014] IEHC 391, [2015] 1 ILRM 1.

${ }^{67}$ Edwards J. noted ([2015] 1 ILRM 1, 58-59) while the trial took place 'in a very different Romania to today's Romania', nevertheless:

'while it is impossible to determine definitively whether the respondent in fact received a fair trial, there is sufficient supporting evidence demonstrating the consistency of her narrative with what is known to have been commonplace in Romania and its criminal justice system at the material time, and concerning the manner in which persons of Roma ethnicity were frequently ill-treated and discriminated against by police and officials within that system, to give the court substantial grounds for believing that there is a real risk that the respondent has suffered a flagrant denial of justice in the requesting country.'

${ }^{68}$ [2008] IESC 3, [2008] 4 IR 42.

${ }^{69}$ Later described by Hardiman J. as a person of 'unblemished character' who 'has had a distinguished career in an Irish public company': Minister for Justice v. Tobin (No. 2) [2012] 4 IR 147, 266. 
While Fennelly J. accepted that the 'fleeing' requirement was not compatible with the requirements of the Framework Decision, he concluded that in view of the express language of the 2003 Act, it could not be construed in a manner compatible with the Framework Decision without giving the Act an interpretation which would be contra legem.

The Oireachtas subsequently enacted the European Arrest Warrant (Amendment) Act 2009, Sect. 6 of which deleted the 'fled' requirement. At that point, the State sought a fresh surrender of Mr. Tobin. A majority of the Supreme Court ultimately refused the request. The two judges of the minority, Denham C. J. and Murray J., took the view that the State was obliged to alter the law in order to ensure that it conformed with the requirements of the Framework Decision, and that obligation effectively superseded any issue concerning the rights of the accused. The majority could not accept this approach and, in lengthy and passionate judgments, they concluded that the surrender would amount to an abuse of process by re-opening a final decision and interfering with vested rights. ${ }^{70}$

\subsubsection{The Presumption of Innocence}

2.3.1.1-2.3.1.2 The automaticity underlying the EAW system has been a constant source of judicial concern for the Irish courts. This can be seen in two important

\footnotetext{
${ }^{70}$ Note, for example, that some members of the majority went to pains to stress that they were entitled to rely on a fundamental legal principle of domestic law - namely abuse of process - in the context of the interpretation of the Framework Decision, provided that the application of these rules did not infringe the principle of non-discrimination or effectiveness. As Fennelly J. observed ([2012] 4 IR 147, 212):

'The legislation was then amended by this State. Indeed this had to be done in order to bring Irish law into conformity with the Framework Decision. That is cold comfort for the appellant. He is the only person whose surrender had been refused by reason of the 'fled' provision. The amendment ... exposed him to the possibility that a second European Arrest Warrant would be issued, which is indeed what has occurred. If the legislation had been enacted originally in conformity with the Framework Decision, he would at least have had his case decided on appropriate grounds. He would either have been surrendered to Hungary or he would have succeeded on appeal on one of the other grounds advanced in Tobin (No. 1). He would not have been subjected to the same judicial process twice.

The consequence of the amending legislation was that the appellant has faced a second process of arrest, objection, High Court hearing and appeal. All this is the result of what appears to have been a legislative error followed by its correction. None of this was the responsibility of the appellant. ... [T] his is quite different from cases where an earlier proceeding has failed by reason of defects in a warrant. In those cases it will be apparent that the surrender ... is the result of a particular defect in the warrant and that ... the error can be remedied and a new warrant can be issued without the defects.

These are in essence the reasons why I agree ... that the appeal should succeed on the ground of abuse of process. The principle of national procedural autonomy permits the courts of the Member States to apply national procedural rules so long as they do not infringe either the principle of non-discrimination or of effectiveness.'
} 
recent Supreme Court decisions in Minister for Justice and Equality v. Bailey ${ }^{71}$ and Minister for Justice and Equality v. Ostrowski. ${ }^{72}$

In Bailey the applicant, a British national, had been a suspect in the murder of a noted French actress, Sophie Toscan du Plantier, in rural west Cork in December 1996. This murder was one of the most controversial murder cases in Irish criminal justice history. The Director of Public Prosecutions decided not to prosecute Mr. Bailey who had been identified as a suspect in the crime. ${ }^{73}$ Section 42 (c) of the 2003 Act as originally enacted had provided that no surrender could take place where the Director of Public Prosecutions had already decided not to prosecute the suspect for the crime in question, but this prohibition was later deleted in $2005 .^{74}$

At that point the French authorities issued an EAW request for Mr. Bailey, but this was ultimately refused by the Supreme Court for two fundamental reasons. First, the Court concluded that it was implicit in Art. 4(7)(b) of the Framework Decision that it imported a requirement of reciprocity. A murder committed outside of Ireland is a crime in Irish law only if committed by an Irish citizen, so that, for example, a court in Ireland could not seek the surrender of a British national in respect of a murder committed in France. It followed that Ireland could not surrender a British national to France in respect of a murder committed in Ireland. Secondly, it was also clear that Mr. Bailey was being sought for the purposes of a preliminary investigation and that no decision had yet been taken to charge the person whose surrender had been sought. ${ }^{75}$

In Ostrowski the surrender of a Polish national was sought on the ground that he was found in possession of $0.72 \mathrm{~g}$ of marijuana. In the High Court, Edwards J. refused to order surrender on the ground that this was wholly disproportionate, not least as the accused was most unlikely to receive a prison sentence in respect of this offence. This decision was, however, reversed on appeal by the Supreme Court. Denham C.J. stressed that once the offence met the minimum gravity test ${ }^{76}$ specified by the 2003 Act, the High Court had no further role in the matter in assessing any question of proportionality. She also took the view that the Irish courts had no role in assessing what type of sentence the offender was likely to

\footnotetext{
${ }^{71}$ [2012] IESC 16, [2012] 4 IR 1.

72 [2013] IESC 24.

${ }^{73}$ This has always been a matter of considerable controversy. It is sufficient perhaps to state that in the course of the EAW proceedings evidence emerged to show that the Director of Public Prosecutions considered that the police inquiry "into the case was "prejudiced" against [Mr. Bailey] and flawed': Minister for Justice v. Bailey [2012] 4 IR 1, 65, per Hardiman J.

${ }^{74}$ Criminal Justice (Terrorist Offences) Act 2005, Sect. 83.

${ }^{75}$ Article 1(1) of the Framework Decision requires that the warrant must be 'for the purpose of conducting a criminal prosecution or executing a custodial sentence or detention order.' Section 21A of the 2003 Act requires the High Court to refuse to order the surrender where the Court is satisfied 'that a decision has not been made to charge the person with and try him or her for the offence specified in the warrant'. See also to same effect, Minister for Justice v. McArdle [2005] IESC 76, [2005] 4 IR 260 and Minister for Justice v. Olsson [2011] IESC 1, [2011] 1 IR 384.

${ }^{76}$ In this case the offence carried a maximum penalty of three years imprisonment.
} 
receive in the requesting state. It is interesting, however, that two other members of the Court, McKechnie J. and MacMenamin J., while concurring in the result, expressed deep unease at this result. Both intimated that the EAW system required revision to ensure that the proportionality of any request was assessed both by the requesting and, indeed, the surrendering state.

\subsubsection{Nullum crimen, nulla poena sine lege}

2.3.2.1 It may seem surprising, given the extensive litigation regarding the EAW, that the issue of nullum crimen sine lege has not featured prominently in Ireland. This is probably because of the protections contained in Sect. 38 of the 2003 Act, the wording of which was provided in the introduction to Sect. 2.3. In the vast majority of cases the requesting state will be required to show that the offence in question has a corresponding Irish offence.

\subsubsection{Fair Trial and In Absentia Judgments}

2.3.3.1 The issue of in absentia judgments has also proved troubling. Section 45 of the 2003 Act contained a general prohibition on surrender for such purposes, but this prohibition has itself been re-cast on two separate occasions. ${ }^{77}$ In the present form, Sect. 45 provides that '[a] person shall not be surrendered under this Act if he or she did not appear in person at the proceedings resulting in the sentence or detention order in respect of which the European arrest warrant was issued, unless the European arrest warrant indicates the matters required by points 2, 3 and 4 of point (d) of the form of warrant in the Annex to the Framework Decision as amended by Council Framework Decision 2009/299/JHA ... '.

It should be noted, however, that the Sect. 45 prohibition is not absolute, reflecting the exceptions expressly provided in Art. 5 of the Framework Decision. ${ }^{78}$ It does not apply to persons who have had adequate notice of the trial but who elect not to participate. ${ }^{79}$ To that extent it may be that Sect. 45 of the 2003 Act is not inconsistent with the decision of the Court of Justice in Melloni. ${ }^{80}$ At the same time, these safeguards are real. Thus, for example, it is inappropriate to order surrender

\footnotetext{
${ }^{77}$ Section 45 of the 2003 Act was first replaced by Sect. 20 of the Criminal Justice (Miscellaneous Provisions) Act 2009. That substitution was itself replaced by Sect. 23 of the European Arrest Warrant (Application to Third Countries) and Extradition (Amendment) Act 2012.

${ }^{78}$ Minister for Justice and Equality v. McCague [2008] IEHC 154, [2010] 1 IR 154, per Peart J.

${ }^{79}$ Minister for Justice and Equality v. McCague [2008] IEHC 154, [2010] 1 IR 154 (the accused who discharged his legal team in advance of a scheduled trial date cannot contend that he was sentenced in absentia, even where the accused contended that he was ill and feared for his life if he attended the trial).

${ }^{80}$ Case C-399/11 Melloni [2013] ECLI:EU:C:2013:107.
} 
where the accused did not appear at the trial, unless the requesting authority has actually completed and filled in the table contained in Sect. 45 of the 2003 Act. $^{81}$

\subsection{4-2.3.5 The Right to a Fair Trial/The Right to Effective Judicial Protection}

See matters covered in previous sections.

\subsubsection{Proportionality and EU Criminal Law}

As can be seen from this brief discussion, the Irish courts have expressed unease with aspects of the operation of the EAW system, particularly its automaticity and lack of proportionality. While there is no doubt that the Oireachtas sought to provide the greatest level of protection possible when enacting the 2003 Act, the courts have struggled to fully live up to these expectations, ${ }^{82}$ as they have felt obliged to give effect to the language and objects of the Framework Decision, ${ }^{83}$ save where to do so would be plainly contra legem. ${ }^{84}$ It should also be noted that the courts have at times expressed unease regarding aspects of the lack of proportionality inherent in the EAW system ${ }^{85}$ and the automaticity involved in giving effect to foreign prosecutorial and judicial decisions. ${ }^{86}$

\subsection{The EU Data Retention Directive}

2.4.1 As it happens, three of the most important data protection cases which have either recently come before the CJEU or are pending before that Court have come

\footnotetext{
${ }^{81}$ Minister for Justice and Equality v. Palonka [2015] IECA 69.

${ }^{82}$ See e.g. the very narrow reading given to the 'protecting constitutional rights' provisions of Sect. 37 of the 2003 Act as demonstrated in cases such as Stapleton and Brennan.

${ }^{83}$ The principle of interprétation conforme as expressed in cases such as Case C-105/03 Pupino [2005] ECR I-05285 features prominently in the Irish EAW jurisprudence. As one might expect, the effect has been in nearly every case to dilute the specific national safeguards contained in the 2003 Act in favour of a more standardised interpretation which conforms with the requirements of the Framework Decision: see generally the comments of Murray J. in Minister for Justice and Equality v. Tokarski [2012] IESC 61.

${ }^{84}$ As happened with respect to the 'fleeing' provisions discussed in Minister for Justice $v$. Tobin (No.1) [2008] IESC 3, [2008] 4 IR 42. See generally, Minister for Justice v. Palonka [2015] IECA 69, per Finlay Geoghegan and Peart JJ.

${ }^{85}$ See, e.g., the comments of Denham C.J., McKechnie and MacMenamin J.J. in Minister for Justice v. Ostrowski [2013] IESC 24.

${ }^{86}$ See, e.g., the disagreement even among the majority in Minister for Justice v. Tobin (No. 2) [2012] 4 IR 147 as to whether the Irish courts could look behind the merits of the Hungarian conviction.
} 
from Ireland: Ireland v. Parliament and Council (2009), ${ }^{87}$ Digital Rights Ireland $^{88}$ and, most recently, Schrems. ${ }^{89}$ These will now be explored in greater detail.

Ireland v. Parliament and Council The first of these cases, Ireland v. Parliament and Council, was a challenge to the legal basis on which the Data Retention Directive $^{90}$ was adopted, with the CJEU rejecting the argument that the Union legislator was not entitled to adopt this provision as an internal market measure. While the case is doubtless an important one in terms of the jurisprudence on internal market measures, it would be hard to say that it had implications for data protection rights as a topic in itself. At the same time, the fact that the action was dismissed may have given the wrong impression that the Directive itself was impregnable to future legal challenge. Many commentators may thus have overlooked the Court's express saver at the commencement of its discussion of the merits of the action:

It must also be stated that the action brought by Ireland relates solely to the choice of legal basis and not to any possible infringement of fundamental rights arising from interference with the exercise of the right to privacy contained in Directive 2006/24. ${ }^{91}$

While the Court acknowledged that data retention is directly concerned with criminal justice and the prevention of terrorism, ${ }^{92}$ it also stressed that this topic has significant implications for the internal market:

It is also clear from the file that the obligations relating to data retention have significant economic implications for service providers in so far as they may involve substantial investment and operating costs.

The evidence submitted to the Court shows, moreover, that the national measures adopted up to 2005 pursuant to Article 15(1) of Directive 2002/58 differed substantially, particularly in respect of the nature of the data retained and the periods of data retention. ...

In the light of that evidence, it is apparent that the differences between the various national rules adopted on the retention of data relating to electronic communications were liable to have a direct impact on the functioning of the internal market and that it was foreseeable that that impact would become more serious with the passage of time.

\footnotetext{
${ }^{87}$ Case C-301/06 Ireland v. Parliament and Council [2009] ECR I-00593.

${ }^{88}$ Joined cases C-293/12 and C-594/12 Digital Rights Ireland and Seitlinger and Others [2014] ECLI:EU:C:2014:238.

${ }^{89}$ Case C-362/14 Schrems [2015] ECLI:EU:C:2015:650.

${ }^{90}$ Directive 2006/24/EC of the European Parliament and of the Council of 15 March 2006 on the retention of data generated or processed in connection with the provision of publicly available electronic communications services or of public communications networks and amending Directive 2002/58/EC, [2006] OJ L 105/54.

${ }^{91}$ Case C-301/06 Ireland v. Parliament and Council, n. 87, at para. 57.

92 Ireland had argued that the 'centre of gravity' of the measure related to the prevention of crime and the protection of national security. Cf. the later comments of the Court in Digital Rights Ireland (at para. 41): ' ... [t] he material objective of that directive is, therefore, to contribute to the fight against serious crime and thus, ultimately, to public security.'
} 
Such a situation justified the Community legislature in pursuing the objective of safeguarding the proper functioning of the internal market through the adoption of harmonised rules. $^{93}$

While there was disappointment in official Irish circles that the objections to the legal basis of the Directive were rejected - it was, after all, the first time in which Ireland had challenged EU legislation on this basis - the Directive was duly transposed into domestic law. Certainly, few were prepared for what happened next.

Case C-293/12 Digital Rights Ireland Digital Rights Ireland Ltd. (DRI) is a company limited by guarantee, which focuses on data protection and data privacy. It sought to challenge in the Irish High Court a direction issued by the Garda (Police) Commissioner instructing telecommunications providers to retain telecommunications data. DRI further challenged the constitutionality of legislation which sought to authorise retention of such data.

Much of the judgment of the High Court is devoted to the question of whether a limited company had locus standi to challenge the validity of this legislation. ${ }^{94}$ Following a review of the Irish constitutional case law on this topic, McKechnie J. granted DRI the right to pursue an actio popularis in relation to interference with constitutional rights to privacy and communications, but not in respect of grounds alleging an interference with marital privacy and the right to travel. Since, however, the state sought to justify the legislation by reference to the Data Retention Directive, McKechnie J. felt that he had no alternative but to make a reference on the validity of the Directive to the CJEU.

The decision of the CJEU in respect of the Art. 267 TFEU reference was that the Directive was invalid having regard to Arts. 7 and 8 of the Charter. ${ }^{95}$ The Court stressed the fact that the Directive permitted the storage of data on an open-ended and undifferentiated basis, and that such interference was significant:

It must be stated that the interference caused by Directive 2006/24 with the fundamental rights laid down in Articles 7 and 8 of the Charter is ... wide-ranging, and it must be considered to be particularly serious. Furthermore ... the fact that data are retained and subsequently used without the subscriber or registered user being informed is likely to generate in the minds of the persons concerned the feeling that their private lives are the subject of constant surveillance.

At the same time the Court observed that the essence of the rights was not affected, as under Art. 1(2) of the Directive, 'the acquisition of knowledge of the content of the electronic communications as such' is not permitted by the Directive. Nevertheless, given that the interference was significant, any interference had to be limited to that which was strictly necessary:

\footnotetext{
93 Case C-301/06 Ireland v. Parliament and Council, n. 87, paras. 68-72.

${ }^{94}$ Digital Rights Ireland v. Minister for Communications [2010] IEHC 221, [2010] 3 IR 251.

${ }^{95}$ Although the plaintiff was also challenging the constitutionality of the legislation in the Irish courts, there appears to have been no reference to the Irish constitutional provisions in the Art. 267 reference itself.
} 
Consequently, the EU legislation in question must lay down clear and precise rules governing the scope and application of the measure in question and imposing minimum safeguards so that the persons whose data have been retained have sufficient guarantees to effectively protect their personal data against the risk of abuse and against any unlawful access and use of that data ... .

The need for such safeguards is all the greater where, as laid down in Directive 2006/24, personal data are subjected to automatic processing and where there is a significant risk of unlawful access to those data .... .

So far as the proportionality of the measure was concerned, the Court noted that it applied to virtually all electronic communications, so that the measure applied to virtually the entirety of the European population. The Court also appears to have been struck by the fact that the Directive did not provide any measured exceptions:

Directive 2006/24 affects, in a comprehensive manner, all persons using electronic communications services, but without the persons whose data are retained being, even indirectly, in a situation which is liable to give rise to criminal prosecutions. It therefore applies even to persons for whom there is no evidence capable of suggesting that their conduct might have a link, even an indirect or remote one, with serious crime. Furthermore, it does not provide for any exception, with the result that it applies even to persons whose communications are subject, according to rules of national law, to the obligation of professional secrecy.

The CJEU further found that the Directive does not require any relationship between the data of which retention is provided for and a threat to public security, e.g. by reference to a particular time period or a particular geographical zone, or a circle of particular persons likely to be involved in a serious crime. Additionally the Directive 'also fails to lay down any objective criterion by which to determine the limits of the access of the competent national authorities to the data and their subsequent use for the purposes of prevention, detection or criminal prosecutions concerning serious offences. Furthermore, Directive 2006/24 'does not contain substantive and procedural conditions relating to the access of the competent national authorities to the data and to their subsequent use'. 'Above all, the access by the competent national authorities to the data retained is not made dependent on a prior review carried out by a court or by an independent administrative body whose decision seeks to limit access to the data and their use to what is strictly necessary for the purpose of attaining the objective pursued ...'. Nor did the measure lay down clear and precise rules regarding the time period during which the data is to be retained. It likewise was found not to have adequate safeguards against potential abuse. The Court further added that:

The directive does not require the data in question to be retained within the European Union, with the result that it cannot be held that the control, explicitly required by Article 8 (3) of the Charter, by an independent authority of compliance with the requirements of protection and security, as referred to in the two previous paragraphs, is fully ensured. Such a control, carried out on the basis of EU law, is an essential component of the protection of individuals with regard to the processing of personal data .... 
Given that the measure failed the proportionality test, it followed that the Directive had to be annulled. It may be significant that the Court did not address questions of retroactivity in its decision.

Schrems v. Data Protection Commissioner The third case, Schrems v. Data Protection Commissioner ${ }^{96}$ arose in judicial review proceedings before the High Court in which the above-named applicant, an Austrian national, challenged a decision of the respondent Data Protection Commissioner (hereinafter Commissioner) not to investigate a particular complaint of his any further pursuant to Sect. 10(1)(b) of the Data Protection Act 1988 (hereinafter 1988 Act). All users in Europe of the major social network, Facebook, are required to sign a contract with Facebook Ireland Ltd. (Facebook Ireland). To that extent, therefore, Facebook Ireland is regulated by the Commissioner under the Irish Data Protection Acts. Facebook Ireland is a subsidiary of its US parent, Facebook Inc. (Facebook). Some or all data relating to Facebook subscribers residing within the EU/EEA is in fact transferred to and held on servers which are physically located within the United States.

The essence of Mr. Schrems' complaint of 25 June, 2013 to the Commissioner was that in the light of the revelations made from May 2013 onwards by Edward Snowden concerning the activities of the US National Security Agency (NSA), there was no meaningful protection in US law and practice in respect of data so transferred to the US so far as State surveillance was concerned.

The Commissioner rejected this complaint on two grounds. First, he considered that there was no evidence that Mr. Schrems' personal data had been accessed by the NSA (or other US security agencies) ('the locus standi objection'), so that the complaint was purely hypothetical and speculative. Secondly, the European Commission had determined in its decision of 26 July, 2000 (2000/520/EC) ('the Safe Harbour Decision') that the United States 'ensures an adequate level of [data] protection' in accordance with Art. 25(6) of Directive 95/46/EC (the 1995 Directive). The Commissioner noted that the Safe Harbour decision was a 'Community finding' for the purposes of Sect. 11(2)(a) of the 1988 Act, so that any question of the adequacy of data protection in that third country (in the present case, the United States) where the data is to be transferred was required by Irish law 'to be determined in accordance with that finding'. As this was the gist of the applicant's complaint - namely, that personal data was being transferred to a third country which did not in practice observe these standards - the Commissioner took the view that this question was foreclosed by the nature of the Safe Harbour Decision.

\footnotetext{
96 [2014] IEHC 310, [2014] 2 ILRM 441 (Irish High Court), Case C-326/14 Verein für Konsumenteninformation [2015] ECLI:EU:C:2015:462 (pending before the CJEU). I should disclose that the author was the referring judge. Nothing in this commentary should be taken as reflecting one way or another on the merits of litigation which is currently pending before the Court of Justice.
} 
The evidence and the findings of fact The High Court of Ireland found the following facts regarding the interception of personal data:

(a) Electronic surveillance and interception of communications in the manner provided by law serves necessary and indispensable objectives which are in the public interest, namely, the preservation of national security and the prevention of serious crime. The surveillance and interception of personal data transferred from the EU to the US by the US National Security Authority (and other similar agencies, both in the US and elsewhere) serves legitimate and necessary counter-terrorism objectives and goals.

(b) Nevertheless, the revelations made by Edward Snowden demonstrated a significant over-reach on the part of those authorities. While there is oversight on the part of the Foreign Intelligence Services Court in the US, this is done on an ex parte and secret basis. EU citizens have no effective right to be heard on the question of the interception and surveillance of their data and, furthermore, decisions taken to access such data are not conducted on the basis of EU law.

(c) While there may be some dispute regarding the scope and extent of some of these programmes, it was clear from the extensive exhibits contained in the affidavits filed in these proceedings that the accuracy of much of the Snowden revelations did not appear to be in dispute. The Court accordingly found that personal data transferred by companies such as Facebook Ireland to its parent company in the United States can thereafter be accessed by the National Security Authority (and other federal agencies such as the Federal Bureau of Investigation) in the course of a mass and indiscriminate surveillance and interception of such data. Indeed, in the wake of the Snowden revelations, the available evidence presently admitted of no other realistic conclusion. ${ }^{97}$

(d) Both Facebook and Facebook Ireland had self-certified pursuant to the Safe Harbour Decision.

National law So far as Irish national law is concerned, Sect. 11(1) of the 1988 Act precludes the transfer of personal data outside of the State, save where that foreign State 'ensures an adequate level of protection for the privacy and the fundamental rights and freedoms of data subjects in relation to the processing of personal data having regard to all the circumstances surrounding that transfer'. The Court then held that the accessing of private communications by the State authorities through interception or surveillance engages the constitutional right to privacy. Further, accessing by State authorities of private communications generated within the home - whether this involves the accessing of telephone calls, internet use or private mail - is also a clear interference with the inviolability of the dwelling as guaranteed by Art. 40.5 of the Constitution. ${ }^{98}$

The Court next held that the mere fact that these rights are thus engaged does not mean that the interception of communications by State authorities is necessarily or

\footnotetext{
97 At paras. 10-13 of the judgment of the Irish High Court, [2014] 2 ILRM 441, 447-448.

98 Paragraphs 47 and 48 of the judgment, [2014] 2 ILRM 441, 457-458.
} 
always unlawful. The Preamble to the Constitution of Ireland envisages a 'true social order' where the 'dignity and freedom of the individual may be assured', so that both liberty and security are valued. Provided appropriate safeguards are in place, the Court ruled that in a modern society electronic surveillance and interception of communications is indispensable to the preservation of State security. It was accordingly plain that legislation of this general kind serves important - indeed, vital and indispensable - State goals and interests, drawing by analogy on the decision of the German Constitutional Court in the Anti-Terrorism Database case ${ }^{99}$ and the comments of the Court of Justice in Case C-293/12 Digital Rights Ireland.

It further held that the importance of these constitutional rights is nonetheless such that the interference with these privacy interests must be in a manner provided for by law, and any such interference must also be proportionate. This is especially the case in respect of the interception and surveillance of communications within the home. While the term 'inviolable' in respect of the dwelling in Art. 40.5 of the Constitution does not literally mean what it says (i.e. the right is not absolute or incapable of being interfered with), the reference to inviolability in this context nonetheless conveys that the home enjoys the highest level of protection which might reasonably be afforded in a democratic society. ${ }^{100}$

The High Court then held that the mass and undifferentiated accessing of personal data generated perhaps especially within the home - such as e-mails, text messages, internet usage and telephone calls - would not pass any proportionality test or could not survive constitutional scrutiny on this ground alone. The potential for abuse in such cases would be enormous and might even give rise to the possibility that no facet of private or domestic life within the home would be immune from potential State scrutiny and observation. Such a state of affairs would be totally at odds with the basic premises and fundamental values of the Constitution: respect for human dignity and freedom of the individual (as per the Preamble to the Constitution); personal autonomy (Art. 40.3.1 and Art. 40.3.2); the inviolability of the dwelling (Art. 40.5) and protection of family life (Art. 41). Drawing on earlier Irish case law, ${ }^{101}$ the Court noted that Art. 40.5 of the Constitution presupposes that 'in a free society the dwelling is set apart as a place of repose from the cares of the world' and assures 'the citizen that his or her privacy, person and security will be protected against all comers', save in a manner provided for by a law which respects the essence of that constitutional guarantee.

The Court then held that a dwelling could not in truth be a 'place of repose from the cares of the world' if, for example, the occupants of the dwelling could not send an e-mail or write a letter or even conduct a telephone conversation if they were not protected from 'the prospect of general or casual State surveillance of such communications on a mass and undifferentiated basis'. The Court observed:

\footnotetext{
9924 April 2003 at paras. 106, 131 and 133, passim.

${ }^{100}$ At paras. 49-50 of the judgment, [2014] 2 ILRM 441, 457, 458.

${ }^{101}$ Such as The People v. O'Brien [2012] IEHC 68.
} 
That general protection for privacy, person and security in Article 40.5 [of the Constitution of Ireland] would thus be entirely compromised by the mass and undifferentiated surveillance by State authorities of conversations and communications which take place within the home. For such interception of communications of this nature to be constitutionally valid, it would, accordingly, be necessary to demonstrate that this interception of communications and the surveillance of individuals or groups of individuals was objectively justified in the interests of the suppression of crime and national security and, further, that any such interception was attended by appropriate and verifiable safeguards. ${ }^{102}$

The Court further held that if this matter were entirely governed by Irish law, then measured by these particular constitutional standards, at the very least a significant issue would arise as to whether the United States 'ensures an adequate level of protection for the privacy and the fundamental rights and freedoms' within the meaning of Sect. 11(1)(a) of the 1988 Act, such as would permit data transfers to that country. Moreover, given the (apparently) limited protection given to data subjects by contemporary US law and practice so far as State surveillance is concerned, this would indeed have been a matter which the Commissioner would have been obliged to investigate.

Accordingly, the Court found that if the matter were to be judged solely by reference to Irish constitutional law standards, the Commissioner could not properly have exercised his Sect. 10(1)(a) powers to conclude in a summary fashion that there was nothing further to investigate.

\section{National law pre-empted by European Union law? The Safe Harbour Decision} The parties agreed, however, that the matter was only partially governed by Irish law and that, in reality, on this key issue of the adequacy of data protection law and practice in third countries, Irish law has been pre-empted by general EU law in this area. ${ }^{103}$ On this point the Court stated:

This brings us to the nub of the issue for the Commissioner. He is naturally bound by the terms of the 1995 Directive and by the 2000 Commission Decision. Furthermore, as the 2000 Decision amounts to a 'Community finding' regarding the adequacy of data protection in the country to which the data is to be transferred, s. 11(2)(a) of the 1988 Act (as amended) requires that the question of the adequacy of data protection in the country where the data is to be so transferred 'shall be determined in accordance with that finding'. In this respect, s. 11(2)(a) of the 1988 Act faithfully follows the provisions of Article 25(6) of the 1995 Directive.

All of this means that the Commissioner cannot arrive at a finding inconsistent with that Community finding, so that if, for example, the Community finding is to the effect that a particular third party state has adequate and effective data protection laws, the Commissioner cannot conclude to the contrary. The Community finding in question was, as we have already seen, to the effect that the US does provide adequate data protection for

${ }^{102}$ Paragraph 55, [2014] 2 ILRM 441, 459.

${ }^{103}$ This is because Sect. 11(2)(a) of the 1988 Act (as substituted by Sect. 12 of the Data Protection (Amendment) Act 2003) effects a renvoi of this wider question in favour of EU law. Specifically, Sect. 11(2)(b) of the 1988 Act provides that the Commissioner must determine the question of the adequacy of protection in the third state 'in accordance' with a Community finding made by the European Commission pursuant to Art. 25(6) of the 1995 Directive. 
data subjects in respect of data handled or processed by firms (such as Facebook Ireland and Facebook) which operate the Safe Harbour regime.

It follows, therefore, that if the Commissioner cannot look beyond the European Commission's Safe Harbour Decision of July 2000, then it is clear that the present application for judicial review must fail. This is because, at the risk of repetition, the Commission has decided that the US provides an adequate level of data protection and, as we have just seen, s. 11(2)(a) of the 1998 Act (which in turn follows the provisions of Article 25(6) of the 1995 Directive) ties the Commissioner to the Commission's finding. In those circumstances, any complaint to the Commissioner concerning the transfer of personal data by Facebook Ireland (or, indeed, Facebook) to the US on the ground that US data protection was inadequate would be doomed to fail.

This finding of the Commission is doubtless still true at the level of consumer protection, but, as we have just seen, much has happened in the interval since July 2000. The developments include the enhanced threat to national and international security posed by rogue States, terrorist groupings and organised crime, disclosures regarding mass and undifferentiated surveillance of personal data by the US security authorities, the advent of social media and, not least from a legal perspective, the enhanced protection for personal data now contained in Article 8 of the Charter.

While the applicant maintains that the Commissioner has not adhered to the requirements of EU law in holding that the complaint was unsustainable in law, the opposite is in truth the case. The Commissioner has rather demonstrated scrupulous steadfastness to the letter of the 1995 Directive and the 2000 Decision.

The applicant's objection is, in reality, to the terms of the Safe Harbour Regime itself rather than to the manner in which the Commissioner has actually applied the Safe Harbour Regime. There is, perhaps, much to be said for the argument that the Safe Harbour Regime has been overtaken by events. The Snowden revelations may be thought to have exposed gaping holes in contemporary US data protection practice and the subsequent entry into force of Article 8 of the Charter suggests that a re-evaluation of how the 1995 Directive and 2000 Decision should be interpreted in practice may be necessary. It must be again stressed, however, that neither the validity of the 1995 Directive nor the validity of the Commission's Safe Harbour decision have, as such, been challenged in these proceedings.

Although the validity of the 2000 Decision has not been directly challenged, the essential question which arises for consideration is whether, as a matter of European Union law, the Commissioner is nonetheless absolutely bound by that finding of the European Commission as manifested in the 2000 Decision in relation to the adequacy of data protection in the law and practice of the United States having regard in particular to the subsequent entry into force of Article 8 of the Charter, the provisions of Article 25(6) of the 1995 Directive notwithstanding. For the reasons which I have already stated, it seems to me that unless this question is answered in a manner which enables the Commissioner either to look behind that Community finding or otherwise disregard it, the applicant's complaint both before the Commissioner and in these judicial review proceedings must accordingly fail. ${ }^{104}$

${ }^{104}$ At paras. 64-70 of the judgment, [2014] 2 ILRM 441, 462-463. 
Given that the critical issue in the present case was whether US law and practice afforded sufficient data protection and that no issue was ever raised in these proceedings concerning the actions of Facebook Ireland or Facebook ${ }^{105}$ as such, the Court took the view that the real question was whether the Commissioner was bound by the earlier findings to this effect by the European Commission in the Safe Harbour Decision. In other words, the Court considered that this was really a complaint concerning the terms of that decision, rather than the manner in which the Commissioner had applied it. ${ }^{106}$ While Art. 3(b) of the Safe Harbour Decision allows the national authorities to direct an entity to suspend data flows to that third country, this is in circumstances where the complaint is directed to the conduct of that entity. Here the real objection was not to the conduct of Facebook as such, but rather to the fact that the Commission has already determined that the US law and practice provides adequate data protection in circumstances where it is clear from the Snowden disclosures that personal data of EU citizens so transferred to the US can be accessed by the US authorities on a mass and undifferentiated basis.

In these circumstances the High Court found that it would be appropriate to refer to the Court of Justice the question whether, having regard in particular to the earlier findings of fact regarding the Snowden disclosures and the subsequent entry into force of Art. 7 and Art. 8 of the Charter and the recent judgment of this Court in Digital Rights Ireland, the Commissioner was bound by the earlier determination of the European Commission in the Safe Harbour Decision as to the adequacy of the data protection offered by US law and practice. The outcome of this reference is currently pending. ${ }^{107}$

\subsection{Unpublished or Secret Legislation}

2.5.1 The rules regarding the promulgation of legislation are contained in Art. 25 of the Constitution, which provides that Bills must be presented to the President for signature. ${ }^{108}$ The critical provisions are Art. 25.4 paras. 1 and 2:

\footnotetext{
${ }^{105} \mathrm{Mr}$. Schrems has made other separate complaints to the Commissioner concerning Facebook, but none of these complaints arose for consideration in these judicial review proceedings.

${ }^{106}$ Paragraph 69 of the judgment, [2014] 2 ILRM 441, 463.

${ }^{107}$ In its judgment in C-362/14 Schrems, n. 89, delivered on 6 October 2015, the Court of Justice held (i) that the Data Protection Commissioner was not so bound and (ii) the Safe Harbour Decision was itself invalid.

108 This is not a pure formality, as the President could elect to refer the Bill to the Supreme Court to test its constitutionality, having first consulted with the Council of State. The Council of State has met on 27 occasions for this purpose, and the relevant Bills have been referred on 15 occasions.
} 
1. Every Bill shall become and be law as and from the day on which it is signed by the President under this Constitution, and shall, unless the contrary intention appears, come into operation on that day.

2. Every Bill signed by the President under this Constitution shall be promulgated by him as a law by the publication by his direction of a notice in the Iris Oifigiuili ${ }^{109}$ stating that the Bill has become law.

These provisions do raise the possibility that a measure may become law before the public can access the text of the new legislation, although the difficulties thereby presented appear to be more theoretical than real. To date the Irish Supreme Court has been largely unsympathetic to arguments of this kind, citing the express language of Art. 25.4. ${ }^{110}$ A curious variation of this problem emerged in Cussens v. Brosnan, ${ }^{111}$ a VAT case where it emerged in the course of an appeal to the Supreme Court that the Irish Revenue Commissioners had withheld the text of a derogation by Ireland from the application of the VAT rules on the disposal of property and, just as remarkably, that the EU Commission had agreed to this. In the light of this admission, the Court gave the appellant leave to amend its pleading based on the emergence of this new fact. ${ }^{112}$

\subsection{Rights and General Principles of Law in the Context of Market Regulation: Property Rights, Legal Certainty, Non-retroactivity and Proportionality}

2.6.1 The question of the protection of property rights and legitimate expectations in the context of EU legislation has rarely arisen in the Irish courts. This is principally because insofar as such a measure interferes with property rights or other procedural entitlements, it will nonetheless be held to be 'necessitated' by the obligations of EU law for the purposes of Art. 29.4.6 of the Constitution and, hence, immune from constitutional review.

\footnotetext{
${ }^{109}$ I.e., the Official Gazette.

${ }^{110}$ Minister for Justice and Equality v. Adach [2010] IESC 33, [2010] 3 IR 402, Minister for Justice v. Bailey [2012] IESC16, [2012] 4 IR 1.

111 [2015] IESC 45.

112 As Laffoy J. commented in her judgment:

'Further, it is difficult to understand how a State body could consider that it had the entitlement to withhold the derogation, which, in reality, is a legal instrument which regulates the charging of VAT and ... can be regarded as part of the law of the land, from a taxpayer's adviser, for example, from Mr. Brennan and other partners of Deloitte. It should have been furnished when it was sought in the context of this appeal in March 2012. While the Court was told, in the course of the submissions, that its withholding was not wilful, in that neither the respondent nor the European Commission was able to find it, there was no evidence to support that. Further, as counsel for the appellants emphasised, by letter dated 12th August, 2002 from the European Commission, Mr. Brennan was informed that the "Irish authorities have informed my services that they do not agree to the release of these documents".'
} 
This was made clear by the Supreme Court's decision in Maher v. Minister for Agriculture and Food. ${ }^{113}$ In that case the plaintiff farmers, who were not at that time milk producers themselves, had leased their milk quotas to other producers from which they derived an income. They challenged the constitutionality of a ministerial order which directed them to either sell back their quotas at par value ${ }^{114}$ or else to resume milk production and cease the leasing of the quota. The Supreme Court held that the order was 'necessitated' by the obligations of the EU milk quota system and was, accordingly, immune from constitutional review. The Court added for good measure that milk quotas were creatures of EU law and as the Court of Justice had ruled that such quotas were not in themselves a species of property rights, ${ }^{115}$ such quotas could not be regarded as a form of property rights for the purposes of Irish constitutional law.

The courts will not, however, interpret national legislation affecting fundamental rights in a manner which is contra legem, even if the ultimate consequence is that the national legislation is interpreted in a manner which is contrary to the intentions of the relevant EU directive. ${ }^{116}$

\subsection{The ESM Treaty, Austerity Programmes and the Democratic, Rule-of-Law-Based State}

2.7.1 Under the Treaty Establishing the European Stability Mechanism (ESM Treaty), Member States may be required to contribute funds to the ESM that in several countries amount potentially to a large proportion of the annual state budget. In Ireland, the liability of the Irish State under the ESM Treaty is 11.1454 billion EUR; the projected Irish Government expenditure for 2015 is 50 billion EUR, and thus the exposure represents some $22 \%$ of the Irish annual budget. The use of such funds is not subject to democratic control or judicial review, and the $85 \%$ majority rule means that smaller states have no say over the use of the funds. The constitutionality of the ratification of the ESM Treaty was, however, directly challenged in Pringle v. Government of Ireland. ${ }^{117}$ Part of the challenge was to the validity of the ESM Treaty itself as a matter of EU law. This aspect of the proceedings ultimately resulted in a reference by the Supreme Court to the Court of Justice which, as is well known, sustained the validity of the treaty. ${ }^{118}$ Independently of

\footnotetext{
${ }^{113}$ [2001] IESC 32, [2001] 2 IR 139.

${ }^{114}$ I.e. at a price lower than the prevailing market price.

115 See e.g. Case 2/94 Bostock [1994] ECR I-00995.

${ }^{116}$ See e.g. Albatross Feeds Ltd. v. Minister for Agriculture and Food [2006] IESC 52, [2007] 1

IR 271.

117 [2012] IESC 47, [2013] 3 IR 1.

${ }^{118}$ Case C-370/12 Pringle [2013] ECLI:EU:C:2012:756.
} 
that decision, however, a majority of the Supreme Court upheld the constitutionality of the ratification of the ESM Treaty without a referendum.

The judgments of the Court are lengthy and complex and do not lend themselves to an easy summary. Both the majority judgments and the minority judgment spend much time on the implications of the earlier Crotty decision. ${ }^{119}$ While the majority judges acknowledged the serious implications of the ESM Treaty, they considered that unlike Title III of the Single European Act which was at issue in Crotty, the ESM Treaty did not involve an abdication of or the fettering of the executive power of the State. They stressed that, on the contrary, ratification of the Treaty involved the exercise of the executive power of the State in the manner contemplated by Art. 29 of the Constitution. The dissenting judge, Hardiman J., dissented principally on the basis that the ESM Treaty

involves a transfer of sovereignty to a degree that makes it incompatible with the Constitution when one applies the principles set out by this Court in Crotty, such that a referendum amending the Constitution is necessary to permit the State to ratify the ESM Treaty on behalf of Ireland. ${ }^{120}$

2.7.2 No significant constitutional issues have been raised with regard to the Banking Union.

2.7.3 Ireland was in an EU sponsored bailout from 2010 to 2013. This bailout proved necessary after Ireland had to spend enormous sums rescuing its banks at taxpayers' expense during 2008-2010, the costs of which threatened to overwhelm the financial stability of the state. Even prior to that period, there had been a series of fiscal retrenchments from the onset of the financial crisis in the mid-summer of 2008. During this period, from 2009 onwards, there were a series of emergency measures reducing public sector pay and other disbursements from public moneys through the Financial Emergency Measures in the Public Interest Acts. The courts have, moreover, almost always consistently rejected all challenges to executive or other decisions designed to give effect to the austerity and deficit reduction programme. Thus, the constitutionality of legislation affecting the pension payments of public servants with privately funded pensions ${ }^{121}$ or effecting significant reductions in payments to pharmacists ${ }^{122}$ or payments to police officers ${ }^{123}$ has been upheld, even though by definition the legislative measures in question adversely affected

\footnotetext{
${ }^{119}$ Crotty v. An Taoiseach [1987] IR 713.

${ }^{120}$ In his dissent, Hardiman J. also drew attention to other potential implications of the Treaty for the budgetary process prescribed by the Constitution. For example, although Art. 17.2 provides that no money shall be appropriated save on a recommendation to the lower House, Dáil Éireann, by the Taoiseach, '[w]hat would be the position, having regard to Art. 17.2, of a future Government, Taoiseach, who did not wish to approve, or to recommend, an appropriation for payments to the ESM to Dáil Eireann?'

${ }^{121}$ Unite the Union v. Minister for Finance [2010] IEHC 354.

122 JJ Haire Ltd. v. Minister for Health and Children [2009] IEHC 562, [2010] 2 IR 615.

123 Garda Representative Association v. Minister for Finance [2010] IEHC 78.
} 
contractual and other entitlements protected by the property provisions contained in Art. 40.3.2 and Art. 43 of the Constitution. The courts have likewise rejected all claims based on legitimate expectations in relation to changes to a teachers' early retirement scheme ${ }^{124}$ or in sick pay benefits for public servants, ${ }^{125}$ with the courts expressly citing the financial crisis as a justification.

There is, perhaps, only one case of this kind where a claimant has succeeded: Dellway Investments Ltd. v. National Asset Management Agency. ${ }^{126}$ In that case the Supreme Court held that the principles of fair procedures were violated when the performing loans of the plaintiff company were transferred to the National Asset Management Agency (NAMA) without giving that company an opportunity to be heard on the matter. NAMA was the 'bad bank' established by the Oireachtas in the wake of the property and banking collapse designed to take major debtors off the books of the Irish banks, so that they could resume lending again in the ordinary way. The Court held that the transfer of these loans to NAMA in practice unambiguously signalled to the markets that there were serious solvency issues arising in respect of the company in question. It followed that the applicant company was entitled to be heard on this question prior to such transfer.

While the decision in Dellway was regarded as a major defeat for the Government, it is nonetheless significant that it was the first and only such reverse so far as the austerity programme was concerned. It is ever more significant perhaps that the decision was based on procedural grounds only, since there was no equivalent at all of the decision of the Portuguese Constitutional Court invalidating a budgetary measure adopted as part an austerity measure on proportionality or similar substantive grounds.

The High Court has also upheld the constitutionality of the legislation (Credit Institutions (Financial Support) Act 2008) giving effect to the banking sector guarantee in September 2008 which was at the heart of the financial crisis: see Collins v. Minister for Finance. ${ }^{127}$ The Court held that the legislation contained sufficient principles and policies which enabled the courts to review decisions taken under the legislation and to ensure democratic accountability. The Court further rejected the argument that the appropriations clause in Art. 11 of the Constitution was violated by the 2008 Act because of the open-ended nature of the guarantee. ${ }^{128}$

${ }^{124}$ Curran v. Minister for Education [2009] IEHC 378, [2009] 4 IR 300.

${ }^{125}$ Garda Representative Association v. Minister for Public Expenditure and Reform [2014] IEHC 457.

${ }^{126}$ [2011] IESC 14, [2011] 4 IR 1.

127 [2013] IEHC 530.

${ }^{128}$ The Court said that it was sufficient for this purpose that:

'the appropriation must be for "an object, to an extent, and out of a fund, which the laws have prescribed." Applying that test to the present case, it can be said that the objects of the appropriation under the 2008 Act are clear and satisfy the requirements of Art. 17.2 [of the Constitution] Section 6(12) of the 2008 Act further provides that the payment comes from the Central Fund in the manner envisaged by Article 11. The extent of the payments are also clear. While, of course, the Oireachtas did not know precisely the sums which were at stake when enacting the 2008 Act, it 


\subsection{Judicial Review of EU Measures: Access to Justice and the Standard of Review}

2.8.1 The number of Irish cases which have been the subject of Art. 267 TFEU references is not high, although the number has begun to rise steadily from a low base in recent years. ${ }^{129}$ Since 2006 , there has been only one instance where a reference has expressly sought the annulment of an EU measure, namely, Digital Rights Ireland (see Sect. 2.4).

2.8.2-2.8.3 So far as the domestic judicial review is concerned, the standard of review is mixed. There is vigorous judicial review of administrative decisions on grounds of fair procedures, adherence to procedural rules and vires. In this area the record of the Irish courts is very good indeed: one might almost regard it as exemplary. So far as substantive review is concerned, the record is more mixed; there is, to some extent, a culture of deference and unwillingness to intervene. This is especially true of specialist agencies such as planning bodies. ${ }^{130}$ There is, however, some sign that this standard of review is regarded as too restrictive, so that a more elaborate review takes place in cases where the protection of fundamental rights is at stake. ${ }^{131}$

So far as domestic constitutional review is concerned, there have been some 94 declarations of unconstitutionality since 1937. While this is in some respects impressive, it might also be said that given the breadth and extent of the fundamental rights guarantees contained in the Constitution, the courts have too often looked away and not engaged sufficiently with major constitutional claims. Against that background, one cannot say from an Irish perspective that the standard of review performed by the Court of Justice in respect of proceedings against EU institutions in matters of economic regulation is lower than that which in practice prevails in ordinary constitutional and judicial review cases in Ireland. ${ }^{132}$

2.8.4 The Irish courts have not yet given any indication of a Solange style rebellion. This is perhaps because the question is to some degree pre-determined by the language of Art. 29.4.6 of the Constitution: if the matter is 'necessitated' by the obligations of EU law, then it is beyond the purview of constitutional review. The

laid down principles and policies in s. 2 and s. 6 of the 2008 Act which circumscribe the extent of the Minister's discretion to provide financial support.'

Article 17.2 of the Constitution provides that the Dáil may not vote for the appropriation of public money without a message signed by the Taoiseach for this purpose.

129 The Court of Justice of the European Union, Annual report 2013, Luxembourg 2014, p. 107, puts the figure at 72 .

${ }^{130}$ See most notably the leading decision in O'Keeffe v. An Bord Pleanála [1993] 1 IR 39.

${ }^{131}$ See e.g. Holland v. Governor of Portlaoise Prison [2004] IEHC 208, [2004] 2 IR 573; Clinton v. An Bord Pleanála [2007] IESC 19, [2007] 4 IR 701; Meadows v. Minister for Justice and Equality [2010] IESC 3, [2010] 2 IR 701 and Efe v. Minister for Justice and Equality [2011] IEHC 414, [2011] 2 IR 798.

132 For relevant case law, see Chalmers et al. 2006, pp. 436-437. 
Irish courts have, by and large, taken an accommodating view of what is 'necessitated ${ }^{133}$ by the obligations of Union law. While there remains uncertainty as to the extent to which discretionary decisions taken within the purview of EU law can be described as 'necessitated' for this purpose, Treaty obligations, decisions of the Court of Justice and the method of implementation of EU legislative measures can all be regarded as 'necessitated' obligations required by EU law.

\subsection{Other Constitutional Rights and Principles}

2.9.1 The other major constitutional issue which has arisen is the method of implementation of EU directives. The Irish courts have, by and large, facilitated the implementation of EU legislative measures by means of ministerial orders made under the European Communities (Amendment) Act 1973, with the Supreme Court reasoning that the practical necessity of transposing such statutory instruments in this fashion means that this method of implementation is itself 'necessitated' and, hence, immune from constitutional review by reason of Art. 29.4.6 of the Constitution. ${ }^{134}$ Following two further decisions which invalidated statutory instruments that were found to have by-passed the prohibition on the creation of indictable offences by means of statutory instruments, ${ }^{135}$ the European Communities Act 2007 now expressly permits a statutory instrument to give effect to EU legislative requirements and to create an indictable offence for this purpose. $^{136}$ This is further discussed in Sect. 1.4.1 above.

\subsection{Common Constitutional Traditions}

2.10.1 Much of the contemporary Irish historical constitutional scholarship has stressed the extent to which many of the substantive provisions have drawn not only on the US Constitution and the UK common law constitutional historical heritage ${ }^{137}$ but also on a variety of continental constitutions, most notably the Weimar Constitution of 1919. ${ }^{138}$ A good example is provided by Art. 40.5 of the

\footnotetext{
${ }^{133}$ Most notably in cases such as Meagher v. Minister for Agriculture and Food [1994] 1 IR 329. See generally Barrett (2013), pp. 154-155.

${ }^{134}$ Meagher v. Minister for Agriculture and Food [1994] 1 IR 329.

${ }^{135}$ Kennedy v. Ireland [2005] IESC 36, [2007] 2 IR 45, Quinn v. Ireland [2007] IESC 16, [2007] 3 IR 395.

${ }^{136}$ Provided that the maximum penalty is now greater than five years imprisonment.

${ }^{137}$ See generally, Keane 1992, p. 25; Jaconelli 1992; O‘Donnell 2014, p. 139.

${ }^{138}$ See generally, Kelly 1983; Hogan 2014, p. 155.
} 
Constitution which provides: 'The dwelling of every citizen is inviolable and shall not be forcibly entered save in accordance with law.'

This has a direct counterpart in Art. 13 of the German Basic Law, which in turn had a corresponding provision in Art. 115 of the (1919) Weimar Constitution. The latter, however, also drew on earlier sources, such as Art. 3 of the French Constitution of 1848 , which provided that the 'residence of every person dwelling in French territory' was 'inviolable'.

It is indeed striking that there has been little comparative analysis of similar constitutional provisions of this kind, of which many unexplored examples abound. As Besselink and others have noted, the references in the case law of the Court of Justice and, for that matter, of the European Court of Human Rights to national constitutions is often perfunctory. ${ }^{139}$ Two reasons may be advanced for this. The first is quasi-legal in nature, since it suits the two European Courts to fashion a new homogenised European jurisprudence in matters of human rights which, while acknowledging the original national sources, seeks to carve out a new jurisprudence which is divorced from and independent of national case law and traditions. The second reason is that it is now almost forgotten that the European standards were (originally) designed to set minimum benchmarks. Thus, for example, the drafters of the ECHR deliberately rejected arguments which had been advanced by, inter alia, the French delegation that Art. 8(1) should protect the 'inviolability' of the dwelling and the 'natural rights deriving from marriage and paternity and those pertaining to the family'. The compromise which was arrived at was that Art. $8(1)$ should simply 'respect' those rights, leaving each state free to have higher domestic constitutional standards. ${ }^{140}$

2.10.2 There are in this context practical mechanisms for rendering the 'common constitutional traditions' a more direct and relevant source in EU law. In the Schrems data protection reference, the Irish High Court drew attention to the manner in which the Irish courts had protected the inviolability of the dwelling and suggested that, drafting differences notwithstanding, Art. 7(1) of the Charter might well be interpreted in a similar fashion.

\subsection{Article 53 of the Charter and the Issue of Stricter Constitutional Standards}

2.11.1 It is, perhaps, not altogether surprising that Art. 53 of the Charter was interpreted in a restrictive fashion by the Court of Justice in Melloni. In effect, Member States are not permitted to have higher constitutional standards where this would jeopardise the uniform application of EU law. Not, perhaps, for the first time,

\footnotetext{
139 Besselink 2012, pp. 137-138.

${ }^{140}$ Hogan 2014, pp. 167.
} 
the wording of the Charter is apt to mislead. As thus interpreted, Art. 53 of the Charter permits Member States to have their own national constitutional standards and to apply them to those cases where either the Charter or, for that matter, EU law is not engaged. It would nonetheless have to be admitted that any other interpretation of Art. 53 would potentially jeopardise the uniform application of EU law.

There has, however, been little discussion in Ireland on whether the Court of Justice should properly set the level of Charter rights at the level of the ECHR, or whether there are areas where there may be a case for increasing the standard to match that provided under the Constitution. This is mainly because it is recognised that the ECHR is the only common template among the Member States which would justify this approach.

\subsection{Democratic Debate on Constitutional Rights and Values}

2.12.1 Fair Trials International has noted that the adoption of the European Arrest Warrant Framework Decision was marked by 'the lack of public engagement in the area of defence rights and the almost total absence of political debate on the subject' (cf. the Questionnaire). This was certainly true in Ireland as much as elsewhere in the EU. The elaborate nature of the safeguards and protections contained in the 2003 Act is largely due to the fact that the Minister for Justice at the time ${ }^{141}$ was a very prominent lawyer who was greatly interested in the entire EAW process and its implications for the administration of criminal justice. There has been even less debate on the question of the EU Data Retention Directive. Unlike in other jurisdictions - such as e.g. Germany - data protection is regarded as an exotic topic which excites few outside of a cadre of specialists.

There is little doubt but that, as the Irish Meagher and Maher case law shows, the need for the speedy and effective transposition of EU directives and the supremacy of EU law dilutes the opportunity for democratic deliberation, constitutional review and accommodation of important constitutional issues. In Meagher the Supreme Court upheld the constitutionality of a procedure whereby a fixed time limit contained in earlier legislation was amended by ministerial order. The Court reasoned that in the circumstances of the substantive prosecution at issue in that case, ${ }^{142}$ it was necessary for the time limit ${ }^{143}$ to be extended to ensure an effective

\footnotetext{
${ }^{141}$ Michael McDowell S.C. Mr. McDowell was a former Attorney General who later held the office of Tánaiste (Deputy Prime Minister).

${ }^{142}$ The applicant had been prosecuted for the possession of illegal animal growth promoting substances which Member States were required by a series of directives to make illegal.

${ }^{143}$ The time limit was extended from six months (in legislation) by two months (by ministerial order).
} 
prosecution system for these offences. ${ }^{144}$ This system of amending legislation by ministerial order was accordingly deemed to be 'necessitated' to give effect to European Union obligations and was accordingly immune from constitutional challenge by reason of Art. 29.4.6 of the Constitution. ${ }^{145}$

Other examples can be given where the decisions of the Court of Justice or the European Court of Human Rights have also effectively lessened or weakened the protection of domestic fundamental rights provided for in Irish constitutional law. One example from the sphere of immigration law and family life is the insurmountable obstacles' line of case law from the ECtHR where that Court has held that there is, generally speaking, no objection on Art. 8 grounds to the deportation of a spouse to that spouse's country of origin where it is reasonable to expect the other spouse to join him or her. ${ }^{146}$ This test has proved very influential with the Irish courts, even though the practical effect of this decision may be that non-national parents are in effect obliged to take their Irish citizen children back with them to their country of origin. ${ }^{147}$ This test has been applied even though Art. 8 ECHR refers merely to 'respect' for family life, whereas Art. 41.1.1 of the Constitution guarantees the 'inalienable and imprescriptible rights' of the family. Some later judgments have dissented from the proposition that the 'insurmountable obstacles' test is the appropriate test to apply in view of the higher standard of protection contained in Irish constitutional law, 'as some weight must be given to the even more emphatic description of family rights contained in Article 41' as compared with Art. 8 ECHR. ${ }^{148}$

In other cases, however, the Court of Justice has shown the way. Thus, for example, the Court's own decisions in $C^{C h e n^{149}}$ and Ruiz-Zambrano ${ }^{150}$ have illustrated how the right of European citizenship contained in Art. 20 TFEU will serve to protect the (third country) parents of minor children who are citizens of the

\footnotetext{
${ }^{144}$ As Blayney J. put it ([1994] 1 IR 329, 360:

'The relevant directives here were binding on the State from the moment they were adopted, "as to the result to be achieved." One result to be achieved clearly was the creation of effective sanctions for the enforcement of the measures contained in the directives. So the State was bound to introduce effective measures, and if this necessitated adopting a measure which impliedly amended an existing statute, that measure would prevail over the statute because it was in substance a measure of Community law. It is really only in form that it is part of the domestic statute.'

145 The reasoning of the Irish Supreme Court in Meagher has met with almost universal criticism in the academic literature. See e.g. the comments of Fahey 2010 at 50 describing the decision as 'an unfortunate case of the Irish judiciary demonstrating yet again that they are excessively pragmatic in this area of the law'.

${ }^{146}$ See, e.g., Boultif v. Switzerland, no. 54273/00, ECHR 2001-IX; Uner v. the Netherlands [GC], no. 46410/99, ECHR 2006-XII.

147 See, e.g., Alli v. Minister for Justice, Equality and Law Reform [2009] IEHC 595, [2010] 4 IR 45.

${ }^{148}$ See, e.g., AO v. Minister for Justice [2012] IESC 79, EA v. Minister for Justice [2012] IEHC 371.

${ }^{149}$ Case C-200/02 Chen [2004] ECR I-09925.

${ }^{150}$ Case C-34/09 Ruiz-Zambrano [2011] ECR I-01177.
} 
Member State in question from deportation where this would have the 'effect of depriving citizens of the Union of the genuine enjoyment of the substance of the rights conferred by virtue of their status as citizens of the Union'. A majority of the Irish Supreme Court had previously reached exactly the opposite conclusion in the context of the operation of the rights of citizenship conferred by Art. 2 and Art. 9 of the Constitution. ${ }^{151}$ That Court has now - tacitly at least - acknowledged that its earlier decision was wrong and that it must be re-considered in the light of Chen and Zambrano. ${ }^{152}$

\section{Constitutional Issues in Global Governance}

\subsection{Constitutional Rules on International Organisations and the Ratification of Treaties}

3.1.1-3.1.4 International relations are regulated in Art. 29 of the Constitution, where the relevant sections provide as follows:

1 Ireland affirms its devotion to the ideal of peace and friendly co-operation amongst nations founded on international justice and morality. ...

3 Ireland accepts the generally recognised principles of international law as its rule of conduct in its relations with other States. ...

$51^{\circ}$ Every international agreement to which the State becomes a party shall be laid before Dáil Éireann.

$2^{\circ}$ The State shall not be bound by any international agreement involving a charge upon public funds unless the terms of the agreement shall have been approved by Dáil Éireann.

$3^{\circ}$ This section shall not apply to agreements or conventions of a technical and administrative character.

As we have already noted, where an international treaty involves a significant derogation from national sovereignty or materially affects the international operation of executive, legislative or judicial powers, a referendum will generally be required to effect constitutional change. This has been the basis of the various constitutional amendments dealing with EU Treaty change, but it also explains the basis for the constitutional amendment dealing with the Belfast Agreement in respect of Northern Ireland and the ratification of membership of the International Criminal Court. The relevant provisions include the following:

$71^{\circ}$ The State may consent to be bound by the British-Irish Agreement done at Belfast on the 10th day of April, 1998, hereinafter called the Agreement. ...

9 The State may ratify the Rome Statute of the International Criminal Court done at Rome on the 17th day of July, 1998.

${ }^{151} A O$ and DL v. Minister for Justice [2003] 1 IR 1.

${ }^{152}$ Okunade v. Minister for Justice [2012] IESC 49, [2012] 3 IR 152. 
Where an international treaty involves a charge on public funds, it must be laid before Dáil Éireann (cf. Art. 29.5.2 above) and the courts will not give effect to any international treaty where this constitutional requirement has not been complied with. For example, a ministerial order giving effect to an Irish-US extradition treaty was found unconstitutional, as the treaty provided for a charge on public funds and it had not received the prior approval of Dáil Éireann. ${ }^{153}$

\subsection{The Position of International Law in National Law}

3.2.1-3.2.2 Article 29 of the Constitution commits Ireland to the classic position of the dualist state, since Art. 29.6 provides that an international agreement has force in domestic law only to the extent that such is provided by the Oireachtas itself:

No international agreement shall be part of the domestic law of the State save as may be determined by the Oireachtas.

In recent times both the Supreme Court and the Court of Appeal have stressed that the effect of this provision is that international agreements do not have, as it were, direct effect in Irish law unless the Oireachtas has clearly indicated to the contrary. ${ }^{154}$

Beyond the rules outlined above and in the preceding section, the Irish courts have nonetheless faithfully given priority to international treaty obligations which have been incorporated into EU legislative instruments. If, as nowadays is often the case, these treaty obligations have been subsumed into an EU legislative instrument, then this will have the effect that, by virtue of Art. 29.4.6 of the Constitution, the treaty (as thus subsumed into EU law) is beyond challenge on domestic law grounds. This can be seen in cases involving the European Arrest Warrant, ${ }^{155}$ but perhaps a better example can be found in one aspect of the Bosphorus Airways litigation.

At the height of the Yugoslav wars, economic sanctions were imposed by means of Council Regulation 990/93/EEC. These sanctions in turn reflected the terms of a UN Security Council resolution to the same effect. Acting pursuant to the sanctions Regulation, the Irish authorities had impounded an airplane owned by Yugoslav Airways but which had been the subject of a dry lease to Bosphorus. The airplane in

\footnotetext{
${ }^{153}$ The State (Gilliland) v. Governor of Mountjoy Prison [1987] IR 201.

${ }^{154}$ See, e.g., McD. v. L. [2009] IESC 81, [2010] 2 IR 199 (European Convention on Human Rights), Sweeney v. Governor of Loughan House Open Prison [2014] IESC 42, [2014] 2 ILRM 401 (European Convention on the Transfer of Sentenced Persons); McCoy v. Shillelagh Quarries Ltd. [2015] IECA 28 (Aarhus Convention outside the scope of EU law).

155 This unhappiness is most notably visible in the judgments of McKechnie J. and MacMenamin J. in Minister for Justice and Equality v. Ostrowski [2013] IESC 24.
} 
question had never returned to Yugoslavia, but had been principally utilised for the purpose of charter flights between Turkey and the rest of Europe. In the High Court Murphy J. stressed that the lease in question was bona fide and did not represent an attempt to circumvent the sanctions in these regulations. Accordingly, he declined to hold that the 1993 Regulation should apply to the situation presented by this case:

As long as the position is that no citizen of Serbia or Montenegro has any use or control over the aircraft in question or the opportunity to receive any income derived from it, then it would seem to me that the regulations have achieved their purpose fully and the impounding of the aircraft would constituted a wholly unwarranted interference in the business of Bosphorus. ${ }^{156}$

The state appealed to the Supreme Court, which in turn made a reference under Art. 267 TFEU (then Art. 177) to the Court of Justice. That Court, however, saw no real difficulty in the manner by which the sanctions operated. It stated that all sanctions regimes might impact on innocent third parties. It continued:

\begin{abstract}
Moreover, the importance of the aims pursued by the regulation at issue is such as to justify negative consequences, even of a substantial nature, for some operators..... the aim pursued by the sanctions assumes especial importance, which is, in particular, in terms of Regulation No 990/93 and more especially the eighth recital in the preamble thereto, to dissuade the Federal Republic of Yugoslavia from 'further violating the integrity and security of the Republic of Bosnia-Herzegovina and to induce the Bosnian Serb party to cooperate in the restoration of peace in this Republic.
\end{abstract}

As compared with an objective of general interest so fundamental for the international community, which consists in putting an end to the state of war in the region and to the massive violations of human rights and humanitarian international law in the Republic of Bosnia-Herzegovina, the impounding of the aircraft in question, which is owned by an undertaking based in or operating from the Federal Republic of Yugoslavia, cannot be regarded as inappropriate or disproportionate. ${ }^{157}$

While Bosphorus Airways may properly be regarded as a special - almost unique case so far as Ireland is concerned, it may nonetheless be thought to illustrate how the decisions of global institutions such as the UN see justice through the prism of a global governance and are, perhaps, less sensitive to the appeals of individuals affected by such measures. No one doubted the grave and terrible humanitarian consequences of the Bosnian War, but it might be thought that the Court of Justice made undeservedly little of the argument that the operation of the sanctions regime had a disproportionate effect on what the Irish court regarded as a bona fide leasing arrangement.

${ }^{156}$ Bosphorus Airways v. Minister for Transport [1994] 2 ILRM 550, 560, per Murphy J.

${ }^{157}$ Case C-84/95 Bosphorus [1996] ECR I-03953. 


\section{3-3.4 Democratic Control and Judicial Review}

See Sects. 3.1 and 3.2.

\subsection{IMF Bailout Programme}

3.5.1-3.5.2 When the bail-out package was announced in December 2010, the issue arose as to whether the agreement with the IMF was an international agreement which involved a charge on public funds for the purposes of Art. 29.5.2 of the Constitution. If it was, Art. 29.5.2 would require that the agreement receive the prior approval of Dáil Éireann (the lower House of Parliament). Although the IMF denied that the agreement was an international agreement for this purpose on the basis that it was a simply a 'letter of intent' to enter into a conditional assistance programme, it awaited the formal approval of the Dáil ${ }^{158}$ before the bail-out package was agreed with the Irish Government.

\section{References}

Besselink L. (2012) General Report. In: Laffranque J. (ed.) The Protection of Fundamental Rights Post-Lisbon, Reports of the XXV FIDE Congress Tallinn 2012, Vol. 1. Tartu University Press, Tallinn, pp. 63-139.

Bradley S.T. (1987) The Referendum on the Single European Act. E.L. Rev. 12:301 et seq.

Casey J.P. (2000) Constitutional Law in Ireland. Sweet \& Maxwell, Dublin.

Chalmers D., Hadjiemmanuil C., Monti G., Tomkins A. (2006) European Union law: text and materials. Cambridge University Press, Cambridge.

Chubb B. (1974) Cabinet Government in Ireland. Institute of Public Administration, Dublin.

Fahey E. (2010) EU Law in Ireland. Clarus Press, Dublin.

Farrell R., Hanrahan A. (2011) The European Arrest Warrant in Ireland. Clarus Press, Dublin.

Foley B. (2010) The BUPA Ireland Case and Constitutional Litigation. Irish Jurist 45:230 et seq.

Geoghegan H. (2014) Crotty put to sleep by Pringle. In: Bradley K., Travers N., Whelan A. (eds.) Of Courts and Constitutions: Liber Amicorum in Honour of Nial Fennelly. Hart, Oxford, pp. 233 et seq.

Hogan G. (1987) The Supreme Court and the Single European Act. Irish Jurist 22:55 et seq.

Hogan G. (1997) The Constitution, Property Rights and Proportionality. Irish Jurist 32:373 et seq.

Hogan G. (2000) The British-Irish Agreement and the Irish Constitution. E.L. Rev. 6:1 et seq.

Hogan G. (2012) The Origins of the Irish Constitution 1928-1941. Royal Irish Academy, Dublin.

Hogan G. (2014) The Influence of the Continental Constitutional Tradition on the Drafting of the Constitution. In: Ruane B., Barniville D., O'Callaghan J. (eds.) Law and Government: A Tribute to Rory Brady. Round Hall, Dublin.

Jaconelli J. (1992) Human Rights and Irish Home Rule. Irish Jurist 25-27:181 et seq.

Keane R. (1992) Fundamental Rights In Irish Law: A Note on the Historical Background. In: O'Reilly J. (ed.) Human Rights and Constitutional Law: Essays in Honour of Brian Walsh. Round Hall, Dublin, pp. 25 et seq.

158725 Dáil Debates, Col. 337 (15 December 2010). 
Keane R. (2014) Reconciling Ireland's Sovereignty with Membership of the European Union - the Lessons of Crotty and Pringle. In: Ruane B., Barniville D., O'Callaghan J. (eds.) Law and Government: A Tribute to Rory Brady, Round Hall, Dublin.

Kelly J.M. (1983) Equality before the Law in Three European Jurisdictions. Irish Jurist 18:259 et seq.

Kelly J.M. (2003) The Irish Constitution, Fourth edn., Tottel, Dublin.

Kenny D. (2014) Proportionality, Burden of Proof and Some Signs of Reconsideration. Irish Jurist 49:141 et seq.

Kiernan F., Brittain S., Donnelly C. (2012) Ireland. In: Laffranque J. (ed.) The Protection of Fundamental Rights Post-Lisbon, Reports of the XXV FIDE Congress Tallinn 2012, Vol. 1. Tartu University Press, Tallinn, pp. 561-580.

O‘Donnell D. (2014) The Most Curious Forerunner. In: Ruane B., Barniville D., O’Callaghan J. (eds.) Law and Government: A Tribute to Rory Brady. Round Hall, Dublin.

Temple Lang J. (1987) The Irish Court Case which delayed the Single European Act. CML Rev. $24: 709$ et seq.

Tomkin A. (2004) Implementing Community Legislation in to National Law: the Demands of a New Legal Order. Judicial Studies Institute Journal (2):130 et seq.

Walsh D.P.J. (2009) The European Arrest Warrant in Ireland: Surrendering Our Standards to a European Criminal Law Area. In Bacik I.C., Heffernan L. (eds.) Criminal Law and Procedure: Current Issues and Emerging Trends. First Law, Dublin, pp. 5-34.

Open Access This chapter is licensed under the terms of the Creative Commons Attribution 4.0 International License (http://creativecommons.org/licenses/by/4.0/), which permits use, sharing, adaptation, distribution and reproduction in any medium or format, as long as you give appropriate credit to the original author(s) and the source, provide a link to the Creative Commons license and indicate if changes were made.

The images or other third party material in this chapter are included in the chapter's Creative Commons license, unless indicated otherwise in a credit line to the material. If material is not included in the chapter's Creative Commons license and your intended use is not permitted by statutory regulation or exceeds the permitted use, you will need to obtain permission directly from the copyright holder.

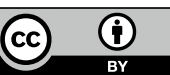

